
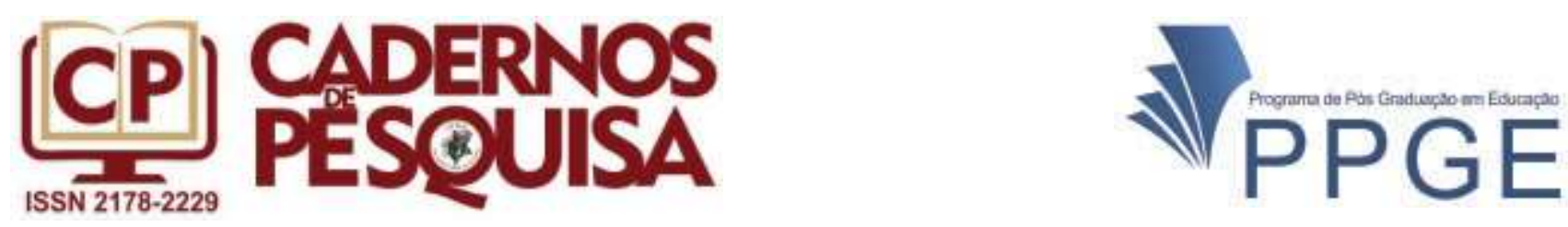

\title{
A EDUCAÇÃO INTEGRAL E O PROGRAMA MAIS EDUCAÇÃO EM ESCOLAS PÚBLICAS DA AMAZÔNIA BRASILEIRA
}

\author{
INTEGRAL EDUCATION AND THE MORE EDUCATION \\ PROGRAM IN PUBLIC SCHOOLS IN THE BRAZILIAN AMAZON
}

\section{EDUCACIÓN INTEGRAL Y EL PROGRAMA MÁS EDUCACIÓN EN ESCUELAS PÚBLICAS DE LA AMAZONÍA BRASILEÑA}

\author{
Diomark Pereira de Araújo ${ }^{1}$ \\ ORCID: http://orcid.org/0000-0003-0268-0794 \\ Edilan de Sant'Ana Quaresma² \\ ORCID: http://orcid.org/0000-0001-7838-783X
}

\begin{abstract}
Resumo: A educação integral e de tempo integral vêm sendo debatidas atualmente com o objetivo de repensar a prática pedagógica, a organização do currículo e redimensionar o tempo e os espaços com a finalidade de oportunizar aprendizagem plena dos alunos. O presente trabalho objetivou resgatar o processo de implantação do Programa Mais Educação realizado em duas escolas urbanas do município de Itaituba, localizado na região Oeste do Pará, na Amazônia Brasileira. Foi realizado por meio da análise documental e de entrevistas com servidores da educação diretamente envolvidos no processo de implantação do referido Programa no município, contemplando, desde suas percepções sobre educação integral e em tempo integral, até detalhes sobre o processo histórico de implementação. Utilizou-se de indicadores educacionais formais para avaliar os resultados da implantação do PME no município, identificando melhorias no desempenho acadêmicos dos estudantes ao longo da execução do Programa, além de apontar para o deficiente preparo do município em receber e implantar o PME nas dependências de suas escolas.
\end{abstract}

Palavras-chave: Educação Integral. Educação em Tempo Integral. Programa Mais Educação. Amazônia.

\begin{abstract}
The whole education and the full-time education are currently being debated with the aim of rethinking pedagogical practice, organizing the curriculum and redimensioning time and spaces in order to provide students with full learning opportunities. The present work aimed to rescue the implementation process of the Programa Mais Educação (PME) carried out in two urban schools in the municipality of Itaituba, located in the western region of Pará, in the Brazilian Amazon. It vas carried out through document analysis and interviews with education workers directly involved in the implementation process of the aforementioned program in the town, covering from their perceptions about full-time and full-time education to details about the historical implementation process. Formal educational indicators were used to assess the results of the implementation of
\end{abstract}

1 Secretaria Municipal de Educação de Itaituba - PA. Grupo de Estudos e Pesquisas HISTEDBR-UFOPA

2 Universidade Federal do Oeste do Pará, Santarém, PA 
the PME in the municipality, identifying improvements in the academic performance of students throughout the execution of the Program, in addition to pointing out the poor preparation of the municipality in receiving and implementing the PME on the premises of their schools.

Keywords: Whole Education. Full-Time Education. Programa Mais Educação. Amazon.

Resumen: La educación a tiempo completo y a tiempo completo se debate actualmente con el objetivo de repensar la práctica pedagógica, organizar el currículo y redimensionar el tiempo y los espacios para brindar a los estudiantes oportunidades plenas de aprendizaje. El presente trabajo tuvo como objetivo rescatar el proceso de implementación del Programa Más Educación realizado en dos escuelas urbanas del municipio de Itaituba, ubicado en la región occidental de Pará, en la Amazonía brasileña. Se realizó a través del análisis documental y entrevistas con los trabajadores de la educación directamente involucrados en el proceso de implementación del Programa mencionado en el municipio, abarcando desde sus percepciones sobre la educación a tiempo completo y tiempo completo hasta detalles sobre el proceso histórico de implementación. Se utilizaron indicadores educativos formales para evaluar los resultados de la implementación del PME en el municipio, identificando mejoras en el desempeño académico de los estudiantes a lo largo de la ejecución del Programa, además de señalar la mala preparación del municipio para recibir e implementar el PME en las instalaciones de sus escuelas.

Palabras-clave: Educación Integral. Educación a tiempo completo. Más programa educativo. Amazonas.

\section{INTRODUÇÃO}

De acordo com Brasil (2015), o Brasil tem passado por desafios no que tange à política educacional brasileira, estando nos últimos anos vinculado, na maioria das vezes, à minimização das desigualdades sociais e a resultados de maior qualidade. Nesse cenário, estão previstas no Plano Nacional de Educação questões estratégicas com o intuito de melhorar a educação, a exemplo, cita-se as grandes diretrizes que versam sobre a implantação das políticas educacionais para os próximos dez anos. Nesse viés, a educação integral torna-se parte da agenda pública, expressa por meio de metas. E dessa parte, surgiu o Programa Mais Educação com fomento para educação integral nos Estados e municípios do Brasil, materializado pela ampliação de sua oferta.

Todavia, para que o Programa Mais Educação fosse implantado no país, como o Brasil, com uma grande diversidade territorial e com singularidades diferentes, seria necessário um olhar diferenciado por parte dos entes federados para que fosse possível fazer as devidas adequações de acordo com cada particularidade, por meio de ações contextualizadas que fizessem sentido e contribuíssem com a política educacional local. Para o desenvolvimento do programa era preciso levar em consideração os desafios, as iniciativas e os aprendizados vivenciados pelos estados e municípios. Ainda que os recursos destinados ao PME fossem repassados diretamente às escolas, esta acabava se beneficiando quando podia contar com o assessoramento e a articulação da rede pública da qual fazia parte. Nesse sentido, foi possível observar que as formas como algumas organizações municipais e estaduais desenvolviam o trabalho, somando seus esforços em relação à educação integral, para que o Programa Mais Educação servisse de inspiração para o aprimoramento da 
iniciativa federal, contribuiu para um maior entendimento de como essa política indutora foi configurada na realidade brasileira.

O trabalho aqui apresentado objetivou resgatar o processo histórico de implantação do Programa Mais Educação em escolas públicas da zona urbana do município de Itaituba, localizado na região Oeste do Pará. Contemplou além de análise documental, relatos de profissionais da educação diretamente envolvidos no referido processo de implantação. Utiliza-se, também, de indicadores educacionais oficiais para realizar uma análise dos resultados advindos da implantação do Programa Mais Educação no município, relacionando tais indicadores com as falas dos entrevistados (diretores, técnicos educacionais, coordenadoras do PME e professores) de vinte e seis escolas contempladas com o PME no município de Itaituba.

\section{A IMPLANTAÇÃO DO PROGRAMA MAIS EDUCAÇÃO EM ESCOLAS PÚBLICAS DO MUNICÍPIO DE ITAITUBA - PARÁ}

O Programa Mais Educação foi aderido pela Secretaria Municipal de Educação/SEMED, no ano de 2009, tendo sua efetivação no segundo semestre do ano de 2010, atendendo, inicialmente, 11.081 (onze mil e oitenta e um) alunos, em 26 (vinte e seis) escolas da Rede Municipal de ensino da Zona Urbana. De acordo com as normas do programa, a contrapartida do município foi nomear dois técnicos da rede municipal de ensino para coordenar o programa, bem como professores comunitários que "eram responsáveis pelo acompanhamento pedagógico e administrativo do Programa [...]" (BRASIL, 2012, p. 8). Para o desenvolvimento dos trabalhos, esses profissionais deveriam ter habilidades para coordenar o processo de articulação com os membros da comunidade, tendo vista a valorização dos saberes locais, e, a partir de sua implantação, passaram a coordenar o programa em 26 escolas, em consonância com os Conselhos Escolares e a Direção Escolar (SEMED, 2019).

De acordo com informações da SEMED (2019), quando o município aderiu ao Programa Mais Educação, não existia uma coordenação exclusiva para atender o programa, pois até o ano de 2015 era denominada de Programa e Projetos (PEP), vinculada ao poder executivo e Secretaria Municipal de Educação (SEMED). A coordenação tinha como atribuições, acompanhar e orientar a execução dos projetos e programas oriundos das esferas Federal, Estadual e Municipal; apoiar os programas e projetos que contribuiriam para o alcance das metas estabelecidas pelas políticas educacionais do município em prol do seu desenvolvimento; adotar ações capazes de produzir resultados que agregassem valor à sociedade e que contribuíssem para melhoria das práticas de gestão, por meio de reuniões e cursos de formação continuada para os segmentos da comunidade escolar que estivessem envolvidos nas atividades de projetos e programas. 
Diante disso, observa-se que apesar de destacar a relevância do acompanhamento dos programas e projetos, não se vê a especificidade na proposta acerca do Programa Mais Educação como política indutora de educação integral, porém é perceptível a clareza de se fazer acompanhamento e orientar a execução dos projetos e programas, tanto do governo federal, estadual, como municipal, mas de forma genérica, sem detalhamento. $\mathrm{O}$ apoio aos projetos surge com a finalidade de alcançar metas estabelecidas pelas políticas educacionais do município em prol de seu desenvolvimento, entretanto, não há clareza em relação a quais metas e quais políticas educacionais. Esse aporte aos projetos seria no sentido de adotar ações capazes de produzir resultados voltados para sociedade e para melhoria das práticas de gestão, porém, sem um maior esclarecimento de qual segmento da gestão.

Apesar de ter sido realizado a adesão do PME pelas escolas em 2009, a efetivação das atividades só foi possível no ano de 2010. Porém é importante frisar que devido aos problemas vivenciados no ano de 2010, a SEMED e os diretores das escolas chegaram ao consenso de que era importante diminuir o número de alunos, pois, segundo a SEMED (2019), as escolas não tinham condições para atender um número expressivo de alunos, o que dificultou os trabalhos no ano de 2010.

A SEMED faz o acompanhamento dos recursos advindos do PDDE às contas das escolas, orientando e realizando junto a cada conselho escolar, no final do ano letivo, a prestação de contas. De acordo com a Resolução ${ }^{\circ}$ 6, de 27 de fevereiro de 2018, as escolas recebem esses recursos em duas parcelas, a primeira até o dia 30 de abril, enquanto a segunda, até o dia 30 de setembro das EExs, UExs e EMs que cumprem as exigências de atualização cadastral até a data de efetivação dos pagamentos. O programa abrange várias ações com finalidades e públicos-alvo com seus particulares, embora a transferência e gestão dos recursos sigam os mesmos padrões operacionais do PDDE (BRASIL, 2017). As ações estão agrupadas em três tipos de contas da seguinte forma:

Quadro 01 - Ações agrupadas para o PDDE. Brasil: 2020

\begin{tabular}{|c|c|c|}
\hline PDDE Integral & PDDE Estrutura & PDDE Qualidade \\
\hline \multirow{2}{*}{ Mais Educação } & Escola Acessível & $\begin{array}{c}\text { Ensino Médio Inova- } \\
\text { dor }\end{array}$ \\
\cline { 2 - 3 } & Água na Escola & $\begin{array}{c}\text { Atleta na Escola } \\
\text { Mais Cultura na } \\
\text { Escola }\end{array}$ \\
\hline \multirow{2}{*}{ Novo Mais Educação } & Escola do Campo & Mais Alfabetização \\
\cline { 2 - 3 } & Escola Sustentável & .
\end{tabular}

Fonte: Site do FNDE (2020). Quadro elaborado pelo autor (2020).

O PDDE é conduzido pela Lei no 11. 947, de julho de 2009, e a resolução do ConseIho Deliberativo do FNDE, com destino às escolas da rede estadual, municipal e do Distrito Federal e privadas, de educação especial, que sejam mantidas entidades sem fins lucrativos, registradas no Conselho Nacional de Assistência Social (CNAS) como beneficentes 
de assistência social, ou outras análogas de atendimento direto e gratuito ao público e aos polos presenciais do sistema Universidade Aberta do Brasil (UAB), que ofertem programas de formação inicial ou continuada a profissionais da educação básica (BRASIL, 2017). Das ações agrupadas pelo PPDE-Brasil, o Programa Mais Educação teve sua terminalidade no ano de 2015 quando passou por uma reformulação, sendo denominado de Programa Novo Mais Educação. Entretanto, importa esclarecer que as últimas 17 escolas que ainda funcionavam com o PNME finalizaram suas atividades em Itaituba no final de 2019 (SEMED, 2020).

No período de 2009 a 2015, quando o PME desenvolveu suas ações, no município de Itaituba, as escolas (A e B) receberam do Fundo Nacional de Desenvolvimento da Educação Básica, recurso pelo PDDE- Educação Integral - Programa Dinheiro Direto na Escola, para contribuir com a melhoria da qualidade da educação por meio da ampliação do tempo de permanência dos alunos nas escolas, como descrito no quadro abaixo:

Quadro 02- Recursos recebidos pelas escolas de Itaituba-PA, 2009-2015

\begin{tabular}{|c|c|c|}
\hline Ano & Escola A & Escola B \\
\hline 2010 & $\mathrm{R} \$: 76.880,60$ & $\mathrm{R} \$: 47.241,60$ \\
\hline 2011 & $\mathrm{NR}^{*}$ & $\mathrm{R} \$: 30.197,60$ \\
\hline 2012 & $\mathrm{R} \$: 34.654,10$ & $\mathrm{R} \$: 32.688,10$ \\
\hline 2013 & $\mathrm{R} \$: 21.950,58$ & $\mathrm{R} \$: 20.648,45$ \\
\hline 2014 & $\mathrm{R} \$: 14.442,56$ & $\mathrm{R} \$: 9.965,32$ \\
\hline 2015 & $\mathrm{R} \$: 14.442,56$ & $\mathrm{R} \$: 9.965,32$ \\
\hline \multicolumn{2}{|c|}{$\mathrm{R} \$: 162.370,40$} & $\mathrm{R} \$: 150.706,39$ \\
\hline TOTAL: & * Escola que não recebeu o recurso por problemas na documentação \\
ou prestação de contas (SEMED, 2020). (Grifo meu). \\
\hline
\end{tabular}

Fonte: Informações obtidas no fnde.gov.br. - PDDE - Educação Integral (2020). Elaborado pelo próprio autor (2020).

O Quadro 02 demonstra o quantitativo de recursos recebidos pelas Escolas A e B, no período de 2009 a 2015, da gênese à finalização do programa. A Escola A, no período em que foi atendida pelo Programa Mais Educação, 2009-2015, recebeu um montante de $\mathrm{R} \$ 162.379,40$ (cento e sessenta e dois mil, trezentos e setenta e nove reais e quarenta centavos). Em 2011, essa escola não foi contemplada com o recurso do PPDE-Integral. Essa situação ocorreu por duas circunstâncias: problemas na documentação ou ausência de prestação de contas por parte da escola (SEMED, 2020). A lacuna entre 2010 a 2012 certamente dificultou a execução do PME, assim como a contribuição para um melhor resultado dos alunos que seriam assistidos pelo programa no ano de 2011. De 2012 para 2015 , observa-se que a escola conseguiu se manter com as obrigatoriedades no que se refere à prestação de constas e organização com a documentação. A escola $\mathbf{B}$, mesmo tendo recebido um montante inferior, de $\mathrm{R} \$$ : $150.706,39$, (cento e cinquenta mil, setecentos e seis 
reais e trinta e nove centavos), de acordo com os dados do quadro, seguiu as regras na prestação de contas, para que o recurso fosse recebido pela escola todos os anos. Diante disso, destaca-se que se essas ações tivessem seguido o real sentido da proposta do PME, com vista a contribuir com os resultados das escolas no que tange ao processo educacional, o programa seguiria um caminho diferente do qual foi sendo efetivado nas escolas.

\section{CARACTERIZAÇÃO DAS ESCOLAS PESQUISADAS}

A pesquisa foi realizada em duas escolas (identificadas como Escola A e Escola B) do município de Itaituba, situadas na Zona Urbana, que desenvolveram atividades relacionadas ao Programa Mais Educação no período de 2009 a 2015. A partir do contato com as escolas, apresentou-se o ofício à direção escolar informando a intenção do pesquisador e um Termo de Consentimento Livre e Esclarecido (TECLE), para os sujeitos arrolados na pesquisa, esclarecendo o objetivo da pesquisa e os instrumentos que seriam utilizados para a coleta dos dados, explicando que a identidade dos sujeitos, assim como das instituições seriam preservadas. Dessa forma, os diretores, os técnicos educacionais, os coordenadores do PME e professores das escolas A e B foram de grande relevância no processo de investigação, contribuindo com a diversidade de olhares acerca da implantação do PME no cotidiano escolar.

\subsection{ESCOLA A}

A Escola A está localizada na Zona Urbana do Município de Itaituba, no Bairro Bela Vista, onde atende a comunidade do entorno e até bairros distantes como Piracanã, Santo Antônio, Residencial Wirland Freire, Maria Madalena, Km 05 dentre outros. A escola contava com um grupo de quarenta e cinco (45) servidores, assim distribuídos: 28 professores, 02 cuidadoras que atendiam os dois níveis ${ }^{3}$ de ensino ofertado pela escola, 01 diretora, 01 vice-diretora, 01 Técnica Educacional, 01 secretária, 02 auxiliares administrativos, 02 vigias, 02 merendeiras e 05 auxiliares de serviços gerais.

\subsection{ESCOLA B}

A Escola $\mathrm{B}$ está situada à $8^{\mathrm{a}}$ Rua, $\mathrm{s} / \mathrm{n}$, Liberdade, fundada no dia 04 de agosto de 1981 com 60 (sessenta alunos), tendo como primeira gestora Maria de Fátima Sousa Lira, na administração municipal do então Prefeito Francisco Xavier Lages de Mendonça.

3 A escola deixou de atender o Ensino Fundamental Maior devido à falta de estrutura para atender os alunos que estudavam Educação Física. Para o desenvolvimento das atividades, os alunos estudavam a disciplina em escola, que tinha quadra Poliesportiva, o que causava transtorno, tanto para a escola que recebia, quanto para a escola de origem. Dessa forma, a comunidade escolar decidiu atender apenas o Ensino Fundamental Menor para minimizar a problemática. 
No dia 04 de março de 1993, a escola passou a funcionar com o $1^{\circ} \mathrm{grau}$, com um total de 163 alunos com turmas de $1^{\mathrm{a}}$ a $2^{\mathrm{a}}$ série. Em 1997, a Escola foi reformada e construída em alvenaria com dois pavilhões, sendo 07 salas de aula, secretaria, sala dos professores, diretoria, banheiros, cozinha, depósito e um refeitório.

Em 20 de novembro de 1998, foi municipalizada através do Decreto Municipal $n^{\circ} \mathrm{EB}$ 131/98, recebendo autorização definitiva para funcionamento de $1^{a}$ a $4^{a}$ série através da Resolução n 132/98 - CEE - PA e para oferta da Educação de Jovens e Adultos por meio da Resolução n 111/06 - CEE - PA, com a finalidade de atender grande demanda estudantil, possuindo quase todas as dependências necessárias para a realização das atividades educativas.

Atualmente, a escola conta com 341 alunos distribuídos em 02 turnos, atendendo alunos da Educação Infantil (Jardim I e II), creche, em anexo, e turmas do de $1^{\circ}$ ao $5^{\circ}$ ano do Ensino Fundamental de 09 anos. A escola conta ainda com 03 auxiliares administrativos, 14 professoras, 02 merendeiras, 04 auxiliares de serviços gerais e 03 vigias.

\subsection{ENTREVISTA COM OS SUJEITOS DA PESQUISA DAS ESCOLAS "A/B"}

Esta seção faz uma abordagem acerca da importância dos sujeitos durante o processo da pesquisa, demonstrando que a participação deles durante a coleta de dados contribui significativamente para a obtenção dos resultados. Com o intuito de atingir os objetivos propostos, foi aplicado um questionário com perguntas abertas e fechadas para dezessete (17) sujeitos, sendo nove (09) da escola A e oito (08) da escola B, assim distribuídos: duas (02) diretoras, duas (02) técnicas educacionais, duas (02) coordenadoras do PME e onze (11) professores. Esse questionário foi de extrema importância para a análise e a interpretação das contradições existentes durante a implantação do Programa Mais Educação no contexto escolar. Para um melhor entendimento dos resultados, o quadro a seguir apresenta o perfil dos sujeitos da entrevista das Escolas A e B que trabalharam na escola durante 0 processo de vigência desse projeto indutor de educação de tempo integral.

Como descrito no Termo de Consentimento Livre e Esclarecido (TCLE), apresentado aos sujeitos da pesquisa para análise dos dados, esclareceu-se que seria utilizada uma codificação para preservar a identidade dos sujeitos arrolados na pesquisa, formada por letras e um número. A primeira letra faz indicação da função do sujeito, (D) Diretor, (TE) Técnico Educacional, $(C P)$ coordenador do programa e $(P)$ para professor; a segunda letra (A ou $B$ ), indica a escola. Para a categoria de professores, foram utilizados números para diferenciá-los. Sendo assim, os sujeitos foram representados dessa forma: DA-Diretor da Escola A; TEA-Técnico Educacional da Escola A; CPA-Coordenador do Programa da Escola A; PA1, PA2...PA6, professores de 1 a 6 da Escola A; DB-Diretor da Escola B; TEB-Técnico Educacional da Escola B; CPB-Coordenador do Programa da Escola B; PB7, PB8...PB11, professores de 7 a 11 da Escola B. 
De acordo com o perfil dos entrevistados, a atuação no âmbito educacional está em um intervalo de 09 a 34 anos de trabalho, que quando associado com a formação específica para este nível de ensino, todos com graduação em Pedagogia. Isto demonstra, portanto, experiência suficiente com função do cargo, a partir do trabalho desenvolvido nas instituições de ensino. O tempo de trabalho e de experiências na função contribuem para um melhor entendimento de como ocorreu a implantação do Programa Mais Educação nas duas escolas de Itaituba. Nesse sentido, observa-se que:

Ao longo da trajetória docente, os professores vivenciam o "Ciclo de vida profissional docente" organizando em fases que expressam como é a inserção do professor na carreira, seus medos, suas dúvidas, suas angústias e seus questionamentos que marcam essa etapa. O decorrer desse ciclo, é marcado por fases que evidenciam a distância entre as ideias e a realidades que surgem, o sentimento de libertação e pertença, sensação de rotina e motivação elevada. O encerramento desse ciclo é marcado por sentimentos como serenidade, conformismo e menos sensibilidade a avaliação dos outros (HUBERMAN, 2000 apud CARDOSO, 2017, p. 4287).

O tempo de serviço com a profissão e com o trabalho desenvolvido nas escolas pesquisadas, contribuiu com o resultado das informações, pois a vivência nas unidades de ensino, a interação social com os companheiros de profissão, certamente os aproximam para falar das certezas e incertezas, alegrias e angústias, das experiências e dificuldades para a realização do trabalho, o que somou para um melhor entendimento de como foi realizada a implantação do Programa Mais Educação.

Além disso, é importante lembrar que todos os entrevistados são formados em pedagogia, uma exigência para o exercício da docência nos anos iniciais, no município de Itaituba, como descrito no art.7 do PCCR, Lei n 2.485/2012, que diz: "a formação exigida para atuar na docência na Educação Infantil e séries/anos iniciais do Ensino Fundamental será de nível Médio na modalidade Normal ou Técnico em Magistério e superior em curso de Licenciatura plena em pedagogia". Portanto, mesmo que ainda haja servidores no quadro efetivo com apenas o magistério, a partir de 2020 a Secretaria Municipal de Educação realizou contrato para servidores com nível superior para trabalhar como professor (SEMED, 2020).

Das escolas pesquisadas, participou da pesquisa apenas um professor do sexo masculino, demonstrando a predominância do sexo feminino nos anos iniciais e nessas escolas também. No Brasil, a docência feminina nasce no final do século XIX relacionada, especificamente, com a expansão do ensino público primário (VIANNA, 2001, p. 83). Antes disso, a profissão docente era exercida por homens, as mulheres trabalhavam no lar. Porém, do século XIX para os dias atuais, o que se vê é feminização ${ }^{4}$ na escola, principalmente nos anos iniciais, resultado de grandes embates para que essa realidade fosse consagrada no meio social.

4 "A maioria dos autores referem-se a feminização ao expressivo número de mulheres que exercem o magistério; apoiada em dados quantitativos" [...] (WERLE, 2005). 


\subsection{A VISÃO DOS SUJEITOS ACERCA DA IMPLANTAÇÃO DO PROGRAMA MAIS EDUCAÇÃO NA ESCOLA}

Esta subseção apresenta os resultados e discussões da análise dos dados por meio das categorias: Concepção de Educação Integral e Implantação do Programa Mais Educação, as quais foram abordadas separadamente para melhor compreender o objeto de estudo.

\subsubsection{Concepção de Educação Integral e em Tempo Integral}

Os sujeitos envolvidos na pesquisa são de fundamental importância no ambiente escolar e, como partícipes do processo de ensino e aprendizagem, devem conhecer o ambiente que compõe a instituição de ensino. Esse conhecimento das particularidades da escola e dos alunos contribuiu significativamente para os resultados da pesquisa. E para análise da categoria sobre Educação Integral, se fez necessário o questionamento aos sujeitos sobre a concepção deles no que tange à Educação Integral e de Tempo Integral, como descrito abaixo:

Educação integral é aquela que forma o ser humano em sua completude (corpo e mente), já a de tempo integral é aquela onde se amplia o tempo de permanência do aluno no espaço escolar. O que vejo como uma complementação de ambas para a formação do ser humano" (DA).

Educação integral e de tempo integral seria ideal se fosse possível, pois em nossa escola não há escolas com estruturas boas, capazes de atender como o mínimo de qualidade nossas crianças [...] (TEA).

Compreendo a Educação Integral como educação no sentido da palavra, completa, que contemple todos os aspectos psicológicos, biológico, formação de valores [...]. E uma Educação de Tempo Integral está se falando especificamente na ampliação da jornada escolar, na ampliação do tempo de educação, mesmo que não se dê especificamente na escola, mas na ampliação desse tempo, que hoje, no nosso sistema seriado, nós temos apenas quatro horas na escola, de segunda a sexta, ou seja, em duzentos dias letivos. [...] (CPA).

A educação integral é o desenvolvimento mais amplo que vai além do currículo escolar, enquanto que a educação de tempo integral é aquela onde o educando passa mais tempo na escola com atividades extras" (P5A).

A meu ver, Educação Integral visa atender o sujeito, garantindo um melhor aprendizado em todas a dimensões (intelectual, física, emocional, social, cultural). Funcionando durante dois turnos, oferecendo um tempo em que a criança participará de atividades culturais, de arte, esporte, ciência e tecnologia" (P7B).

A Educação Integral é um projeto muito bom, mas requer estruturas nas instituições de ensino adequadas [...]. Vejo um lado negativo, pois os alunos ficam mais na escola, do que em casa com a família (P10B). 
De acordo com a fala dos sujeitos, é possível perceber a similaridade em algumas concepções acerca de Educação Integral e de Tempo Integral, assim como ideias divergentes. As respostas demonstram as singularidades dos sujeitos, o "jeito" de pensar a política pública trabalhada no ambiente escolar, resultado da experiência vivenciada na prática, no período em que o PME esteve presente nas instituições de ensino. Diante disso, Pestana (2013, p. 21-27) define Educação Integral como:

A concepção de Educação Integral ganha, contemporaneamente, novos contornos políticos, epistemológicos e metodológicos, principalmente a partir do avanço das políticas de ampliação do tempo escolar. [...] é uma pergunta que não se responde fácil e prontamente. Pode-se dizer, como princípio de explicação, que Educação Integral é o ato de educar voltado para a integridade da formação do sujeito [...] (Grifo meu).

A compreensão de educação integral não é de simples entendimento, como destacado pela autora Pestana (2013), e na contemporaneidade está relacionado aos avanços das políticas públicas, principalmente a de ampliação do tempo escolar. Em análogo ao entendimento abordado, os sujeitos DA, CPA, P5A e P7B apontam para o mesmo entendimento. Para eles, a Educação Integral envolve todos os feitos das ações humanas, ou seja, os aspectos afetivos, físicos, social e intelectual, proporcionando, dessa forma, o desenvolvimento integral do ser humano, o que vai além de um simples currículo formal.

Observa-se, nesse sentido, a preocupação dos sujeitos TEA e P10B, no que tange às questões estruturais, pois, segundo eles, para a implantação do PME nas unidades de ensino, seria relevante a existência de um espaço físico adequado, com estruturas adequadas para o desenvolvimento das atividades, o que não foi possível, tendo em vista que as escolas que ofereceram o programa não dispunham desse tipo de ambiente. A iniciativa da implantação do PME foi necessária, tendo em vista os problemas vivenciados em relação à aprendizagem dos alunos na realidade brasileira. Portanto, o PME surgiu com o objetivo de ampliar a jornada escolar e reorganização curricular, visando a educação integral. Entretanto, para que a política indutora de educação integral atingisse sua meta, era relevante que ela fosse trabalhada de acordo com suas proposições estabelecidas pelo programa, proporcionando ao aluno uma aprendizagem de forma integral.

Para CPA, educação integral e de tempo integral se complementam. A primeira volta-se para a completude da formação humana, psicológico, biológico, formação de valores, em um sentido mais religioso, no qual as famílias tenham a preocupação para uma formação que contemple os valores morais e éticos. Portanto, uma educação que abranja a totalidade da criança, que por meio de uma diversidade de conteúdo, possa ampliar as suas habilidades artísticas, contribuindo para o seu desenvolvimento integral. Porém, apesar de frisar que elas se complementam, esclarece que educação de tempo integral focaliza a ampliação do tempo na escola, acrescentando mais três horas de trabalho nas instituições de 
ensino, ampliando o tempo comumente trabalhado nas escolas brasileiras, de uma carga horária mínima de 4 horas para uma jornada de 7 horas. A exemplo disso, está descrito na LDB, Lei № 9.394/96, em seu artigo 24, que: "a educação básica, nos níveis fundamentais e médios, está organizada de acordo com as regras comuns: I - a carga horária mínima anual de oitocentas horas, distribuídas por um mínimo de duzentos dias de efetivo trabalho escolar, excluído o tempo reservado aos exames finais, quando houver" (BRASIL, 2005, p. 14).

A educação integral é aquela voltada para os programas educacionais que, em sua dinâmica de trabalho, será oferecida por meio de uma diversidade de atividades, de cunho esportivo, cultural, bem como da ampliação do currículo, com o intuito de proporcionar às crianças e jovens melhores condições de aprendizagem. Todavia, para que isso ocorra, é necessário um trabalho coletivo, com a participação de todos, pois com esse modelo de educação, surge outras demandas a serem observadas como a saúde, esporte, inclusão digital e a cultura. Por isso, é relevante articular outros sujeitos, o tempo e o espaço para que seja possível a contemplação do maior número de alunos em atividades, para que essa concepção de vida e de trabalho possa canalizar para a concretização dos objetivos da Educação Integral. No entanto, essa metodologia de trabalho só será possível se houver consenso entre os mais diversos segmentos da sociedade. Em contrapartida, a Educação de Tempo Integral se configura como um ato de compromisso, que se preocupa com a formação integral, sendo que, independente de classes sociais, todos devem ser tratados de forma igualitária, sendo assim:

A educação de tempo é, antes de tudo, um compromisso. Compromisso esse que não se aplica às políticas assistencialistas, mas que traz a integridade de formação omnilateral por meio da ampliação da jornada escolar como oportunidade de uma educação pública de elevada qualidade. O que se pretende então, é que a Educação em Tempo Integral não proponha a superação do ensino organizado por disciplinas, mas a criação de condições de ensinar em função das relações dinâmicas entre as diferentes disciplinas com o diferencial do maior tempo para desenvolver conteúdos que estejam sistematizados e articulados com o currículo da escola, fruto de um planejamento adequado e não da realização de atividades que sejam produtos de improvisação e do acaso (PARANÁ, 2012, p. 7-15, grifo meu).

A educação de tempo integral é um compromisso assumido por meio das secretarias de educação junto às escolas, que contribui para a qualificação da política pública de educação de tempo integral. Um compromisso que não se aplica à política assistencialista, mas que seja dada a oportunidade de trabalhar o ser humano de forma integral, em todas as suas dimensões, por meio da ampliação da jornada escolar, "que não se baliza apenas na ampliação do tempo escolar, mas se paute, na construção de uma educação de qualidade" (PARANÁ, 2012, p. 90). Portanto, a educação de tempo integral não pode ser confundida com a educação integral, mas é o caminho, uma indução que dá a oportunidade para ga- 
rantir a formação integral dos sujeitos, observando as peculiaridades locais, históricas e culturais.

Dessa forma, a educação integral e de tempo integral vêm sendo debatidas atualmente com o objetivo de repensar a prática pedagógica, a organização do currículo e redimensionar o tempo e os espaços com a finalidade de oportunizar aprendizagens dos alunos (PARANÁ, 2012). Todavia, aumentar o tempo de aula sem dar condições da efetiva aprendizagem, poderá recair ao instrucionismo, contrapondo o objetivo da política de educação de tempo integral. Por isso, é importante repensar a função social da escola, sua organização curricular, verificando a maneira como se vem ensinando na prática cotidiana a fim de que o ambiente não se limite apenas à transmissão de conteúdo. Na oportunidade, os sujeitos, a seguir, falaram acerca dos critérios para a escolha do Coordenador do PME:

\begin{abstract}
Em primeiro lugar, acredito que a pessoa deve querer e ter formação para atuar em coordenação. E se teve critérios para a escolha, na implantação do Programa, digo que não, que foi feito um aproveitamento de alguns docentes que estavam readaptados de sua função (DA). (Grifo meu).

De acordo com a coordenadora, a primeira coisa que elenca é que para coordenar o Programa Mais Educação e ser monitor, o profissional deveria ser pedagogo, uma ideia que sempre tive e que foi implantada enquanto fui coordenadora. Sempre dava a preferência para quem fosse pedagogo, estudantes de pedagogia ou que tivesse o magistério. Por que o pedagogo? Porque ele tem uma formação mais para esse olhar, ainda mais que na época em que estava na coordenação do PME, a escola trabalhava com o Ensino Fundamental de anos iniciais e finais. Portanto, a preferência era que fosse pedagogo, depois colocava profissionais de outras disciplinas. O coordenador do programa, além dessa formação, deve acreditar no programa, conhecer o programa e, acima de tudo, ter o comprometimento, o compromisso com a aprendizagem do aluno. Se ele não acredita naquilo que ele faz, naquilo que ele está executando, ele não vai procurar dinâmicas diferentes, não vai procurar alternativas, propostas diferentes para fazer acontecer aquele programa, então tem que ter comprometimento, e não utilizar como um cabide de emprego, como muitas vezes aconteceu (CPA).
\end{abstract}

De acordo com a resposta dos entrevistados, exceto da DB, que na contramão das respostas dos sujeitos, disse que para trabalhar no PME o coordenador deveria "ser habilidoso, se identificar com o trabalho pedagógico, usar a criatividade (ser criativo)", A maioria dos entrevistados disseram que para trabalhar com o PME era necessário ter formação, ser graduado, pedagogo, ou, ao menos, ter magistério, "mas acima de tudo, ter responsabilidade, compromisso e dinâmico" (CPB). Esse profissional além de querer desenvolver o trabalho, precisava ser habilidoso e responsável com o desenvolvimento das atividades. Porém, o que chamou atenção foi a resposta da DA, a qual fez um destaque relacionado à escolha dos profissionais que trabalhariam no Programa Mais Educação. Esses servidores eram, em sua maioria, professores readaptados, e muitos deles permaneceram no PME até a sua finalização. 
Essa era uma das políticas realizadas pela SEMED, pois esses profissionais da educação precisam ser lotados, mas não em sala de aula, visto que o laudo médico os proibiam de exercer a função de docente, mas o certo é que precisavam ser lotados em atividades de cunho pedagógico, então o programa era o campo ideal para esse fim. Importa destacar que esses trabalhadores, por terem algum problema de saúde, precisavam se ausentar com frequência para tratamento ou fazer consultas e exames de rotinas em outros municípios, demandando tempo e com isso, problematizando a efetivação do PME. Dessa forma, logo se observa as dificuldades que esses profissionais enfrentaram para realizar o trabaIho com alunos no contraturno, tendo em vista a necessidade de uma participação mais efetiva por parte de quem coordenava.

Dessa forma, os agentes que trabalhavam diretamente com o PME (diretores escolares, professores, monitores, coordenadores e técnicos educacionais) vivenciaram, na prática, os desafios para a implantação do PME por meio de todos os saberes e linguagens proporcionados pelo programa, tendo em vista que as crianças e jovens deveriam ter, no mínimo, melhor qualidade na aprendizagem. Contudo, percebeu-se que mesmo ocorrendo formação de professores, reuniões com diretores, como descrito pela SEMED (2019), os trabalhos realizados, em relação às disciplinas de Língua Portuguesa e Matemática, voltavam-se para "reprodução" de conteúdo, desestimulando, dessa forma, o interesse dos alunos por essa atividade proposta na escola, dificultando a finalidade do PME.

\subsubsection{Critérios para a escola participar da implantação do Programa Mais Educação}

Esta subseção tem como objetivo analisar a concepção dos entrevistados sobre os critérios de escolha do Programa Mais Educação, abordando os desafios e as possibilidades para a melhoria da qualidade de ensino na escola. O critério para a escolha do PME vivenciado nas escolas pesquisadas foi compreendido pelos entrevistados conforme relatado a seguir:

\footnotetext{
No primeiro momento, não foi escolha das escolas, foi a Secretaria Municipal de Educação que cadastrou as escolas, então veio toda aquela situação, as escolas não estavam preparadas. De 2009 a 2011, foram anos de muitas dificuldades, e mais para a frente, 2012, o que nós percebemos, a escola que passava a aderir, a escola que pedia as atividades que deveria trabalhar, a escola que escolhia que atividades queriam ofertar, quais os alunos deveriam participar. De início, muito de cima para baixo, surgindo muitos desafios (CPA).
}

Além da coordenadora do PME, a diretora da escola A também relatou que para a escola participar do PME considerou-se no "início os dados de rendimento da escola, como o IDEB e as que tinham sido contempladas com o PDDE, pois estas escolas se enquadravam dentro de um nível de vulnerabilidade social muito grande". O professor P2A disse que 
"ocorreu através da adesão ao programa devido ao baixo rendimento dos alunos em Língua Portuguesa e Matemática". E para o professor P9B, a escolha "ocorreu de uma forma boa, vinha o dinheiro para o programa. Era feito as oficinas e tinha tempo determinado para ser gastar tudo para se aplicar conforme a coordenação determinava".

De modo geral, observa-se que não há um consenso nas respostas dos entrevistados, de um lado, dizem que para as escolas participarem do PME, a SEMED fez a adesão do PME e as escolas deveriam aceitar para a efetivação do projeto, mesmo sem condições estruturais, ocorrendo de cima para baixo. De outro lado, as escolas passaram a aderir, além de que a comunidade teve a oportunidade de participar da tomada de decisões, e, a partir disso, as oficinas foram selecionadas, cujo objetivo era a melhorar a qualidade de ensino. Todavia, chama-se a atenção para a fala da diretora da escola A e do professor P2B, os quais disseram que para a escola participar do Programa Mais Educação, considerou-se o baixo rendimento dos resultados obtidos no Índice de Desenvolvimento da Educação Básica-IDEB, como descrito nas figuras 1 e 2 , postas abaixo:

Figura 1 - IDEB da Escola A - Resultados e Metas, no intervalo de 2009-2015 (Itaituba-PA)

\begin{tabular}{|c|c|c|c|c|c|c|c|c|c|}
\hline \multicolumn{10}{|c|}{$4^{\mathrm{a}}$ série $/ 5^{\circ}$ ano } \\
\hline \multicolumn{5}{|c|}{ Ideb Observado } & \multicolumn{5}{|c|}{ Metas Projetadas } \\
\hline $2009=$ & $2011=$ & $2013 \neq$ & $2015 \neq$ & 2017 * & $2007 \div$ & $2009=$ & $2011 *$ & $2013=$ & $2015=$ \\
\hline 3.6 & 4.0 & 4.3 & 4.3 & 5.1 & & 4.2 & 4.6 & 4.8 & 5.1 \\
\hline
\end{tabular}

Fonte: INEP/MEC $(2020)^{5}$.

Figura 2 - IDEB da Escola A - Resultados e Metas, no intervalo de 2009-2015 (Itaituba-PA) $8^{\mathrm{a}}$ série/ $9^{\circ}$ ano

\begin{tabular}{|c|c|c|c|c|c|c|c|c|c|}
\hline \multicolumn{5}{|c|}{ Ideb Observado } & \multicolumn{5}{|c|}{ Metas Projetadas } \\
\hline $2009=$ & $2011 \uparrow$ & $2013=$ & $2015 \%$ & $2017 \div$ & $2007=$ & $2009 \div$ & $2011 \div$ & $2013=$ & $2015=$ \\
\hline 3.6 & 4.0 & 4.3 & 4.3 & 5.1 & & 4.2 & 4.6 & 4.8 & 5.1 \\
\hline
\end{tabular}

Fonte: INEP/MEC (2020) ${ }^{6}$.

Fazendo uma análise dos dados elencados nas figuras um (1) e dois (2) supracitadas com as respostas dos entrevistados, observa-se que no intervalo de 2009 a 2015, a Escola A não atingiu a meta projetada para os anos iniciais do Ensino Fundamental.

5 * Obs: Número de participantes no SAEB insuficiente para que os resultados sejam divulgados. ** Sem média no SAEB 2017: Não participou ou não ateneu os requisitos necessários para ter o desempenho calculado. Os resultados marcados em verde referem-se ao Ideb que atingiu a meta. Disponível em: <http://ideb. inep.gov.br/. Acesso em: 04/05/2020.

6 Obs: * Número de participantes no SAEB insuficiente para que os resultados sejam julgados. ** Sem média no SAEB 2017. Não participou ou não atendeu os requisitos necessários para ter o desempenho cal- 
Divergente dos anos iniciais, os anos finais do Ensino Fundamental, no intervalo de 2009 a 2015, atingiu a meta no ano de 2011, mas em 2015 não obteve os mesmos resultados. Esses resultados foram critérios para a escola ser contemplada com o Programa Mais Educação para que a instituição de ensino pudesse, na posterioridade, melhorar o rendimento escolar. A figura 3, descrita a seguir, faz alusão aos resultados da Escola B que, segundo os entrevistados, mesmo com as dificuldades para implantação, seguiu-se a proposições abordadas no Programa Dinheiro Direto na Escola (PDDE) para que a instituição atingisse as metas projetas.

Figura 3 - IDEB da Escola B - Resultados e Metas, no intervalo de 2009-2015 (Itaituba-PA)

$$
4^{\mathrm{a}} \text { série } / 5^{\circ} \text { ano }
$$

\begin{tabular}{|c|c|c|c|c|c|c|c|c|c|}
\hline \multicolumn{5}{|c|}{ Ideb Observado } & \multicolumn{5}{|c|}{ Metas Projetadas } \\
\hline $2009 \div$ & $2011 *$ & 2013 * & 2015 * & 2017 * & $2007 \div$ & $2009=$ & $2011 *$ & $2013=$ & 2015 * \\
\hline 3.9 & 4.4 & 3.7 & 4.4 & 5.7 & & 4.2 & 4.5 & 4.8 & 5.1 \\
\hline
\end{tabular}

Fonte: INEP/MEC/ (2020) ${ }^{7}$.

A Escola B, diferente da Escola A, no intervalo de 2009 a 2015, ultrapassou a meta projeta, chegando a 3 pontos de diferença da projeção. Porém, importa destacar que esta escola trabalha apenas com turmas do $1^{\circ}$ ao $5^{\circ}$ ano, do Ensino Fundamental Menor. Fazendo um comparativo com as respostas das entrevistas, percebe-se um frágil entendimento acerca da implantação do PME, haja vista que a implantação não foi apenas um resultado da aceitação do Programa Mais Educação, mas uma ação por parte do Ministério da Educação para a construção de uma agenda de indução à educação integral. Os critérios postos nas entrevistas surgiram com várias ações e, por meio delas, outras ações foram ligadas à saúde, à vulnerabilidade social que tinha como objetivo diminuir a repetência dos alunos com dificuldade de aprendizagem, mediante a melhoria do processo de ensino e aprendizagem (SANTOS, 2016).

De acordo com Brasil (2015), o Brasil tem passado por desafios no que tange à política educacional brasileira, estando nos últimos anos vinculado, na maioria das vezes, à minimização das desigualdades sociais e a resultados de maior qualidade. Nesse cenário, estão previstas no Plano Nacional de Educação questões estratégicas com o intuito de meIhorar a educação, a exemplo, cita-se as grandes diretrizes que versam sobre a implantação das políticas educacionais para os próximos dez anos. Nesse viés, a educação integral torna-se parte da agenda pública, expressada por meio de metas. E dessa parte, surgiu o

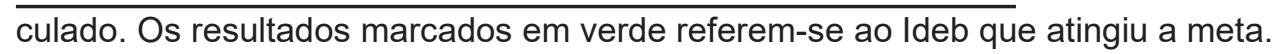

7 * Obs: Número de participantes no SAEB insuficiente para que os resultados sejam divulgados. ** Sem média no SAEB 2017: Não participou o não atendeu os requisitos necessários para ter o desempenho calculado. Os resultados marcados em verde referem-se ao Ideb que a atingiu a meta. 
Programa Mais Educação com fomento para a educação integral nos Estados e municípios do Brasil, materializado pela ampliação de sua oferta, bem como, com a ampliação do tempo escolar. No entanto, "somente a ampliação do tempo não garante uma educação integral, o que pode possibilitá-la é a forma como esse tempo é ocupado, independentemente de ser parcial ou integral" (COLARES et al., 2016, p. 48).

Todavia, para que o Programa Mais Educação fosse implantado no país, como o Brasil, com uma grande diversidade territorial e com singularidades diferentes, seria necessário um olhar diferenciado por parte dos entes federados para que fosse possível fazer as devidas adequações de acordo com cada particularidade, por meio de ações contextualizadas que fizessem sentido e contribuíssem com a política educacional local. Para o desenvolvimento do programa era preciso levar em consideração os desafios, as iniciativas e os aprendizados vivenciados pelos estados e municípios. Ainda que os recursos destinados ao PME fossem repassados diretamente às escolas, esta acabava se beneficiando quando podia contar com o assessoramento e a articulação da rede pública da qual fazia parte. Nesse sentido, foi possível observar que as formas como algumas organizações municipais e estaduais desenvolviam o trabalho, somando seus esforços em relação à educação integral, para que o Programa Mais Educação servisse de inspiração para o aprimoramento da iniciativa federal, contribuiu para um maior entendimento de como essa política indutora foi configurada na realidade brasileira.

Além disso, observou-se na resposta dos entrevistados que não foi possível nesta pesquisa uma resposta aprofundada acerca dos critérios para a implantação do PME no ambiente escolar, o que chama atenção, tendo em vista que de acordo com os dados da SEMED (2019), a Coordenação do PME realizou várias formações desde sua gênese no município de Itaituba. Se o programa foi orientado a partir de um olhar para a própria comunidade com adaptações que abrissem caminhos e possibilidades para que, a partir da sua implantação, viabilizasse o desenho de políticas de ações próprias de acordo com as necessidades da escola, a sua consolidação aconteceria de forma positiva.

Em um dos relatos, ficou claro que a inserção do Programa Mais Educação de início não foi realizada com a participação da escola, mas por imposição da Secretaria Municipal de Educação (SEMED), sendo concretizado de cima para baixo. As escolas não estavam preparadas para o recebimento do programa o que, por conseguinte, gerou desconforto, insegurança e dificuldades para a execução da implantação do PME.

No entanto, segundo a resposta da Coordenadora do PME da escola A, a partir de 2012 as escolas passaram a fazer as adesões, com direito à escolha das oficinas e dos alunos que iriam participar do programa. A LDB nº 9.394/96 (BRASIL, 1996) expressa no Art. 15 que "os sistemas de ensino assegurarão às unidades escolares públicas de educação básica progressivos graus de autonomia pedagógica e administrativa e de gestão financeira, observadas as normas gerais de direito financeiro público" (Grifo meu). 
Nota-se, neste sentido, que, de início, a autonomia da escola não foi respeitada, desafiando o trabalho da gestão escolar, a qual não foi informada no princípio da adesão do PME pela SEMED, esclarecendo que as escolas que se adequassem aos critérios, seriam contempladas. Tendo como base as respostas dos sujeitos, percebe-se que após adesão realizada pela SEMED tiveram que aceitar o programa e realizar as atividades, tornando-se, a partir disso, um desafio para a gestão escolar em contraponto ao descrito no Art. 15 da Lei de Diretrizes e Bases da Educação Nacional, n 9.394/96, onde se faz alusão ao direito de escolha das escolas tanto financeira quanto pedagógica e administrativa.

Dessa forma, é importante frisar que a escola conhece a sua realidade, o perfil socioeconômico dos alunos, suas dificuldades de aprendizagem. E quando essa autonomia não é respeitada, principalmente para a realização de um trabalho da dimensão do PME, chega-se à conclusão que os resultados não poderiam ser diferentes, que haveria dificuldades para viabilidade da política pública nas escolas. No que tange a melhoria da qualidade de ensino e aprendizagem dos alunos a partir da inserção do Programa Mais Educação na escola, seguem as respostas dos entreverados:

Muito embora esse aprendizado tenha sido muito mais nas áreas sociais e culturais, do que o saber exigido em sala de aula [...], porque as áreas mais desenvolvidas como (dança, capoeira) são conhecimento pouco aproveitados. Na leitura e matemática, se houve avanço, foi sutil (P2A).

$\mathrm{Na}$ sala de aula não víamos muitos resultados diferenciados nos alunos que faziam parte do programa (P4A).

[...] não houve retorno positivo no quesito aprendizagem. Enquanto professor não observei melhoria na aprendizagem (P5A).

Acredito que se houvesse um diálogo entre a equipe do programa e os educadores em relação ao processo ensino e aprendizagem e conteúdos trabalhados, principalmente nas oficinas de português e matemática, o avanço seria real. Faltou diálogo entre a equipe do programa e os educadores a respeito do processo de ensino aprendizagem dos alunos, parecia um reforço aleatório (P6A).

Não, porque precisaria mais comprometimento por parte dos monitores. Os educadores do contra turno participavam das aulas, mas desmotivados (P8B).

Na minha opinião, muito pouca aprendizagem, devido o profissional não estar qualificado para determinada oficina. Quando iniciou os três primeiros ou quarto anos foi muito bom, depois disso, mudou a coordenação e monitores, parece que estavam ali por estar, sem compromisso e nem responsabilidade (P9B).

Na verdade, na minha opinião, houve melhoria em parte, pois se faz necessário que haja maior empenho por ambas as partes, [...] precisa de mais investimento para de fato haver melhorias significativas no ensino-aprendizagem dos alunos (P10B). Em partes o Programa teve uma grande contribuição no que diz respeito ao desenvolvimento do aluno, na parte lúdica (P11B).

Para alguns sujeitos, o PME contribuiu para a melhoria da qualidade de ensino proporcionando aos alunos uma interação social, resultado de um trabalho dinâmico e diferenciado. Mas essa aprendizagem só foi possível, segundo a Diretora da Escola B, porque, 
nas oficinas, os monitores trabalhavam com jogos diversificados o que contribuiu para a ampliação do conhecimento dos alunos em Português e Matemática. Porém, é importante deixar claro que para os sujeitos P4A, P5A, P6A, P8B, P9B, P10B e P11B não houve meIhoria e teceram críticas no que se refere ao desenvolvimento das atividades do programa.

Como justificativa, os sujeitos disseram que os profissionais que trabalhavam com as oficinas não tinham habilidades para certas atividades propostas, não havia diálogo dos monitores com os professores da sala regular de ensino, o que dificultava a dinâmica de trabalho cotidianamente, e o investimento não era suficiente para a realização das atividades junto à escola. Além disso, pela fala do $\mathrm{P} 4 \mathrm{~A}$, constata-se que os conhecimentos sociais e culturais não estavam sendo percebidos pela escola e o que ocorreu foi de forma sutil. Logo se vê, que o PME não estava sendo compreendido e trabalhado como postulado por suas diretrizes.

Para aprofundar o entendimento, faz-se necessário fazer um paralelo entre o que os sujeitos abordam acerca da melhoria da qualidade do ensino e aprendizagem com o espelho das informações postas no site do INEP, em relação aos resultados em Língua Portuguesa e Matemática (BRASIL, 2017). Abaixo, uma demonstração da taxa de aprovação das Escolas A e B:

Gráfico 01 - Taxa de Aprovação da Escola A e B - SAEB: 2009-2015

Escola A

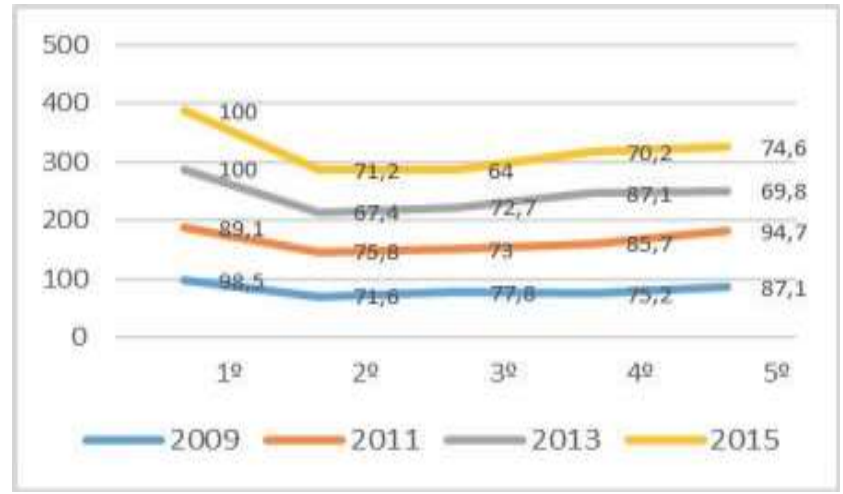

(b) Escola B

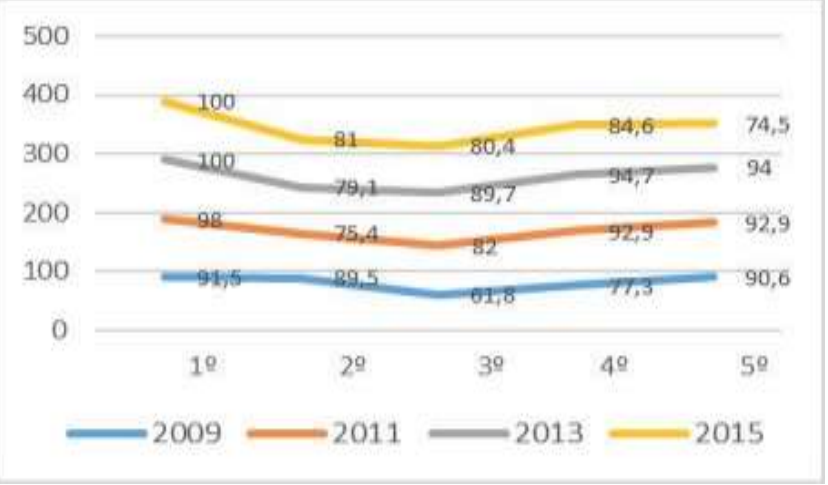

Fonte: INEP/MEC (2017). Elaborado pelo autor (2020).

O Gráfico 01 faz uma comparativo, de modo geral, da taxa de aprovação das escolas A e B, no período de 2009 a 2015. Mesmo não tendo alcançado os resultados projetados, o gráfico acima demonstra que as escolas tiveram melhora no desempenho anual ao longo desse período. Porém, nas turmas dos quintos anos, turmas que participaram das avaliações do Ideb nas edições elencadas, observa-se oscilação nos resultados. Fazendo um comparativo de 2009 com 2015, observa-se que a escola $\mathbf{A}$ teve uma queda nos resultados de 87,1 para 74,6 , um diferencial de 12,5 . Nesse mesmo comparativo, com a escola $B$, de 2009 e 2015, os resultados também não foram positivos, houve uma baixa nos resultados de 90,6 para 74,5 , um diferencial de 16,6 . 
Gráfico 02 - Proficiência Média e Padronizada da Escola A - SAEB: 2009-2015
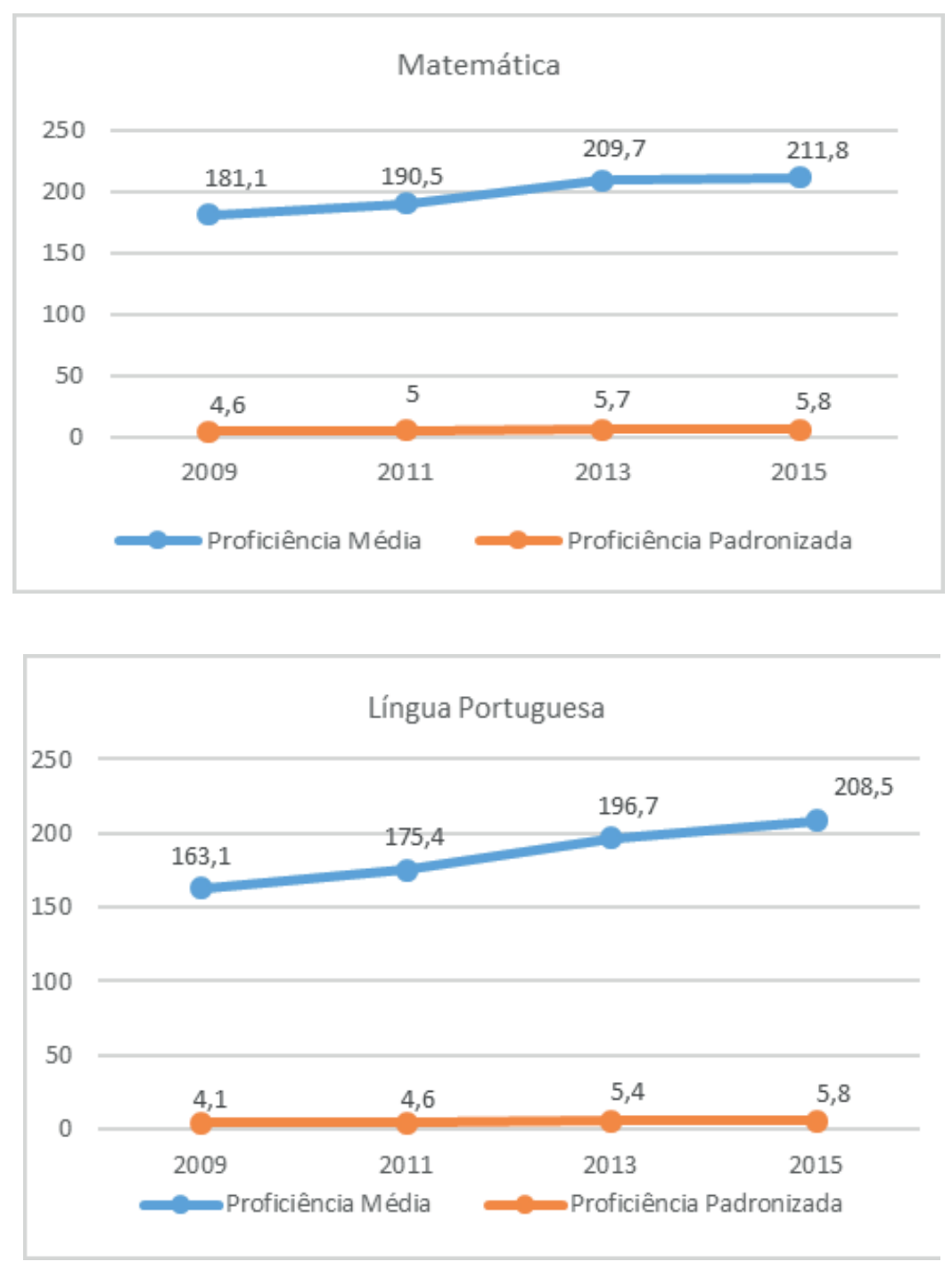

Fonte: INEP/MEC (2017) . Elaborado pelo autor (2020).

De acordo com a Nota Técnica do Saeb (1997), a proficiência média em Língua Portuguesa para a $4^{\mathrm{a}}$ série/ $5^{\circ}$ ano do Ensino Fundamental é de 186.5 e para Matemática é de 190.8. Diante disso, observa-se que a Escola A, tanto em Língua Portuguesa quanto em Matemática está acima da média. Na proficiência padronizada, avalia-se as escolas por uma escala de 0 a 10, cuja média é 5,0 para as turmas da $4^{a}$ série $/ 5^{\circ}$ ano do Ensino Fundamental Menor. Sendo assim, a unidade de ensino obtive avanços nas duas disciplinas, ultrapassando a média padrão de 5,0 para 5,9 em Matemática e 5,9, em Língua Portuguesa.

O Índice de Desenvolvimento da Educação Básica (IDEB), é um indicador de qualidade educacional que faz uma combinação das informações de desempenho em exames padronizados da Prova Brasil ou Saeb, alcançados pelos estudantes ao final das etapas

8 Resultados em Língua Portuguesa e Matemática da participação no SAEB. Disponível em: <http://idebescola.inep.gov.br/>. Acesso em: 07/05/2019. 
de ensino, $4^{\mathrm{a}}$ e $8^{\mathrm{a}}$ séries, atuais $5^{\circ}$ e $9^{\circ}$ anos, do Ensino Fundamental e $3^{\mathrm{a}}$ série do Ensino Médio, como informações sobre o rendimento escolar, INEP (2017). (Grifo meu).

Dessa forma, a proficiência média e padronizada possibilita um melhor entendimento da evolução da escola nas duas disciplinas, Matemática e Língua Portuguesa. Essa visualização dos dados mencionado acima, mesmo indo na contramão da resposta dos sujeitos P4A, P5A, P6, P8B, P9B, P10B e P11B, corrobora a fala da diretora Escola B quando diz que a instituição de ensino sempre priorizou atividades nas oficinas que tinham relação com essas disciplinas da base nacional comum.
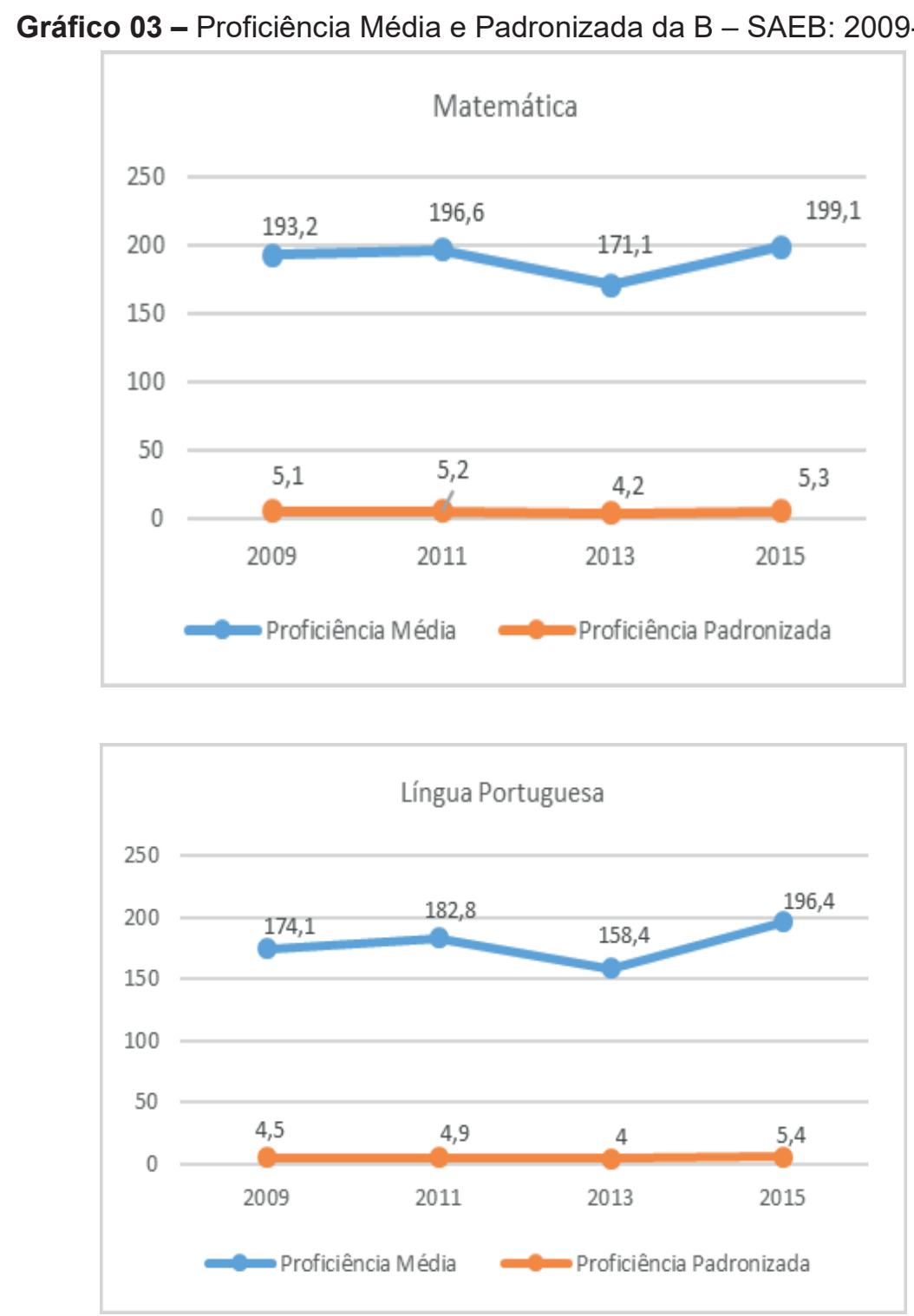

Fonte: INEP/MEC (2017)9. Elaborado pelo autor (2020).

9 Resultados em Língua Portuguesa e Matemática da participação no SAEB. Disponível em: <http://idebescola.inep.gov.br/>. Acesso em: 07/05/2019. 
Na Escola B, mesmo tendo proficiência média e padronizada menor do que a Escola "A", os resultados estão acima da projeção estabelecida pelo Saeb, reforçando o entendimento de que essas escolas tiveram avanços nos resultados propostos por esse tipo de avalição em larga escala. Para um melhor entendimento, o Gráfico 03 faz uma demonstração do comparativo na média padronizada das duas Escolas, "A" e "B", tendo como indicador a escala de 0 a 10. Nessa amostra, é possível perceber que, mesmo de forma tímida, as escolas tiveram avanços no intervalo de 2009 a 2015, pois a escola A teve um acréscimo de 4,38 para 5,8, uma diferença de 1,42.

Divergente da escola "A", a escola "B" teve um avanço de 0,51 , uma diferença entre as duas escolas de, 0,91. Apesar de compreender que cada escola tem suas peculiaridades, os resultados demonstram os esforços conjugados com toda a equipe da instituição (equipe administrativa, técnica, professores, alunos e família). É por meio de um trabalho coletivo que os resultados poderão ser positivos no final de cada ano letivo ou de processos avaliativos de longa escala.

A escola por si só não atinge os objetivos e metas com trabalhos isolados, é preciso uma participação da família junto ao processo de ensino e aprendizagem dos alunos, para que nos anos subsequentes as metas possam ser atingidas e melhoradas. Por isso, se cada segmento da escola unir forças para o bem comum da instituição, os resultados não poderão ser diferentes, a não ser positivos. Diante disso, é importante destacar que a escola precisa abrir possibilidades para o de debate de ideias com vista a melhorar a aprendizagem dos alunos no contexto escolar. Não há como conhecer os problemas, acertos e erros da escola quanto a aprendizagem dos alunos se não tiver o espaço para discussões e consenso do que precisa melhorar.

Gráfico 04 - Proficiência Média e Padronizada de Matemática a Língua Portuguesa:

\section{9-2015}

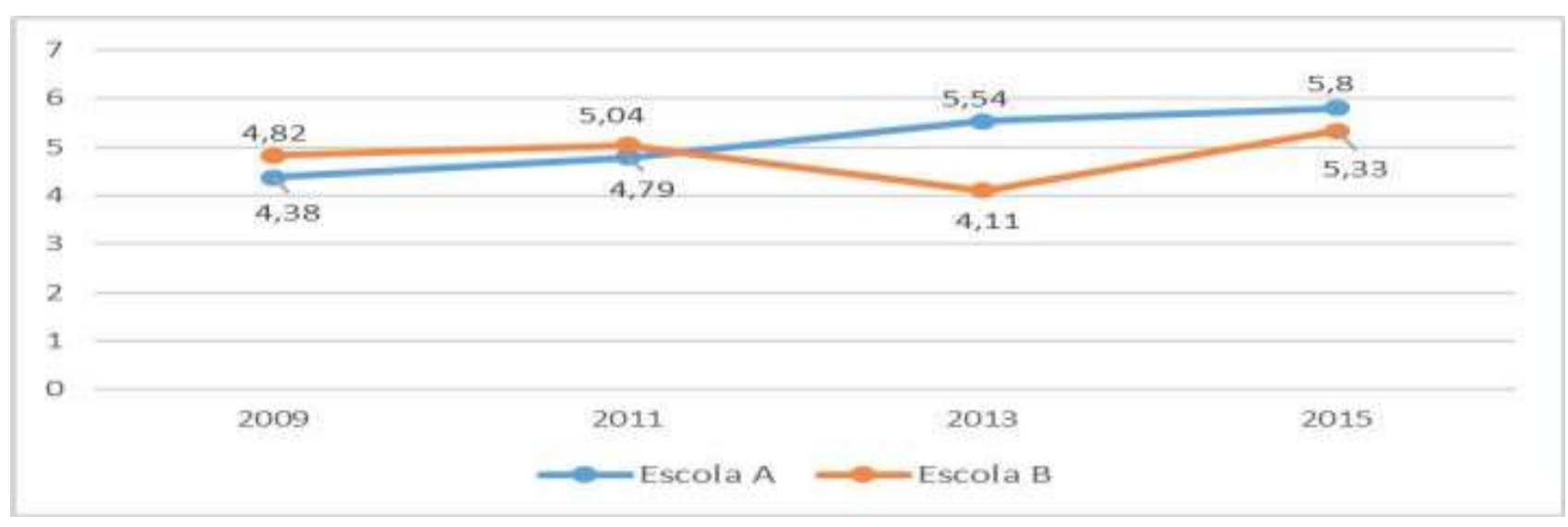

Fonte: INEP/MEC $(2017)^{10}$. Elaborado pelo autor (2020).

$\overline{10} \quad \mathrm{~N}^{*}$ Média $d a$ proficiência em Língua Portuguesa e Matemática, padronizada para um indicador entre 0 a 10, dos alunos da escola, obtida em determinada edição do exame realizado ao final da etapa de ensino. 
E por fim, os gráficos abordados, em seguida, ratificam as observações anteriores, pois a Escola A, na projeção, obteve avanços nos resultados dando um "salto" de 3,6 de 2009 para 4,3 em 2015, com uma diferença de 0,7 pontos equivalendo a um aumento de 19,4\%, sempre com tendência crescente. O desempenho da Escola B no IDEB, no período de 2009 a 2015, também se mostrou positivo com queda nos resultados de 2013, e uma diferença de 0,5 pontos no período o que equivale a um aumento de 12,8\%. Em ambas as escolas, entretanto, o desempenho no IDEB esteve abaixo da meta projetada pelo MEC.

Gráfico 05 - Resultados no IDEB Escolas A e B.2009 a 2015
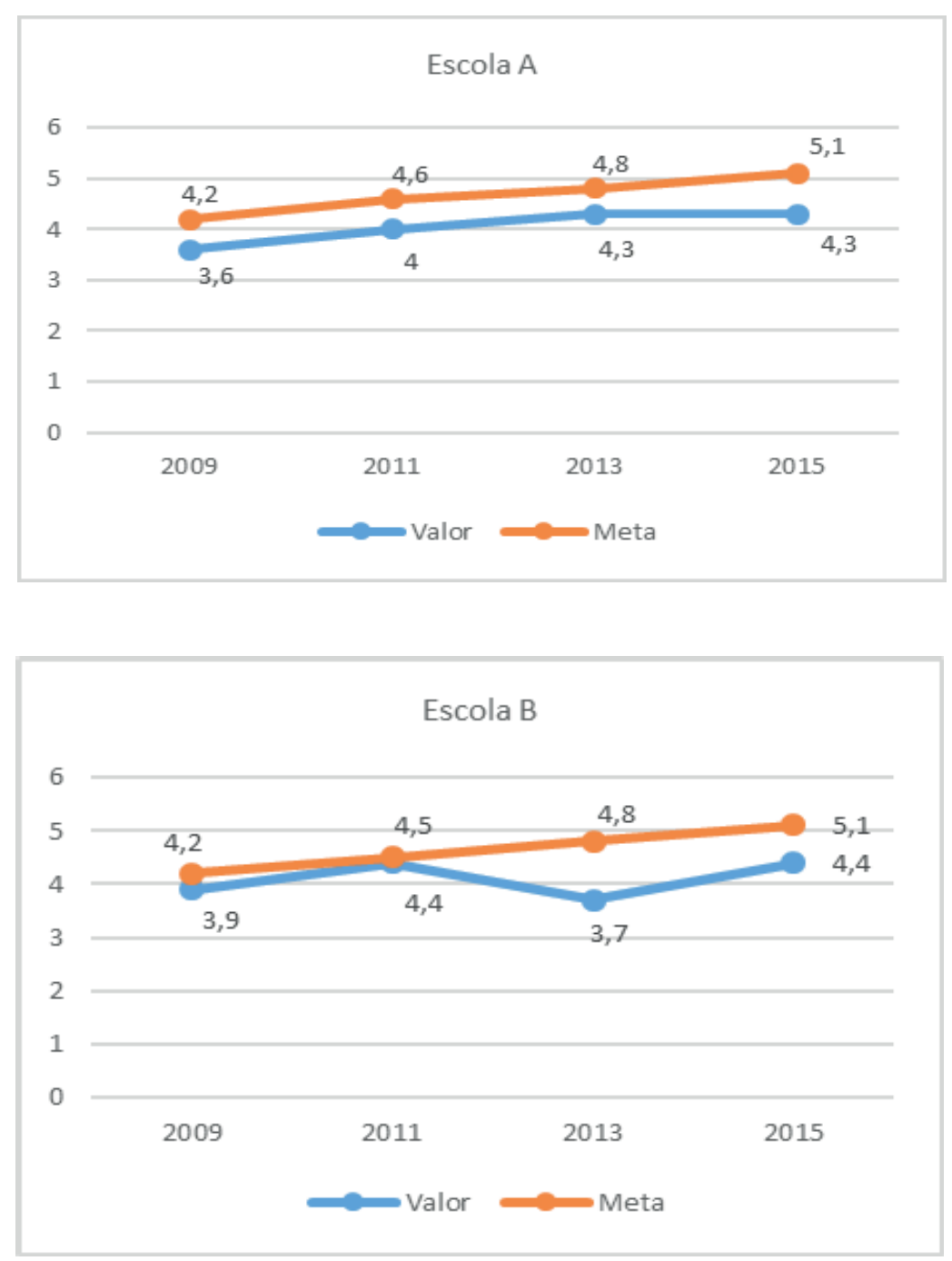

Fonte: INEP/MEC (2017). Elaborado pelo autor (2020).

Na sequência, os sujeitos fizeram uma abordagem das mudanças em decorrência do PME: 
Quadro 03 - Mudanças em decorrência do PME nas Escolas. Itaituba-PA

\begin{tabular}{|c|c|}
\hline Elementos alterados & Opiniões dos respondentes \\
\hline Recursos pedagógicos & $\begin{array}{l}\text { "A partir da implantação do Programa Mais Educação, a escola } \\
\text { adquiriu diversos recursos materiais a saber: Microsystems, compu- } \\
\text { tadores, caixa de som amplificada e jogos pedagógicos" (TEA). } \\
\text { "Em relação ao professor na sala regular, nada, porque os materiais } \\
\text { e equipamentos eram exclusivos para o programa" (P6A). } \\
\text { Pela verba recebida da escola, tivemos aquisição de muitos kits de } \\
\text { jogos pedagógicos, papéis e outros materiais, melhorou demasiada- } \\
\text { mente a questão de material (TEB). } \\
\text { "Disponibilizou jogos educativos que acrescentaram o conhecimento } \\
\text { tanto no lógico quanto na Língua Portuguesa" (P7B). } \\
\text { "Quanto ao material, não houve muita mudança. O material é muito } \\
\text { restrito e precário" (P11B). }\end{array}$ \\
\hline $\begin{array}{l}\text { Projeto pedagógico da } \\
\text { escola }\end{array}$ & $\begin{array}{l}\text { "Foram desenvolvidas ações em parceria com o Programa Mais } \\
\text { Educação" (TEA). } \\
\text { "Na minha opinião, nada" (P5A). } \\
\text { "Nada, porque o programa acontecia separadamente" (P6A). } \\
\text { "Infelizmente não tenho conhecimento que diz respeito a projeto } \\
\text { pedagógico da escola" (P11B). }\end{array}$ \\
\hline Aprendizagem dos alunos & $\begin{array}{l}\text { "Houve pouca mudança na aprendizagem dos alunos, pois muitos só } \\
\text { vinham para almoçar e brincar" (TEA). } \\
\text { "Não vi mudança positiva" (P6A). } \\
\text { Houve uma modificação, alguns modificaram e melhoram em sala } \\
\text { de aula, outros não. Alguns vinham só pelo almoço, simplesmente } \\
\text { (TEB). } \\
\text { "Muito pouco, por conta dos profissionais que estariam ali por estar, } \\
\text { eu vi que não havia interesse para fazer um bom trabalho" (P9B). }\end{array}$ \\
\hline
\end{tabular}

Fonte: Elaborado pelo próprio autor a partir dos dados da pesquisa, 2020.

De acordo com as respostas dos entrevistados, as escolas receberam bastante recursos para aquisição de materiais pedagógicos, os quais foram utilizados nas atividades do Programa Mais Educação. O professor 1 disse que não percebeu mudanças porque, segundo ele, os materiais eram os mesmos. Seguindo o mesmo entendimento, os professores 6 e 11 frisaram que não houve mudança porque os recursos tinham o seu destino, pois eram utilizados exclusivamente nas atividades do PME. Os recursos que foram destinados aos trabalhos do programa contribuíram com a questão material, as escolas estavam abastecidas nesse aspecto. Segundo o professor 9, os materiais contribuíam para trabalhar com a parte lúdica dos alunos, mas o grande desafio era a falta de um bom acompanhamento por parte dos monitores do programa, as crianças ficavam por conta deixando, nesse sentido, a desejar nas atividades. Porém, apesar disso, o professor 7 relata que os recursos ampliaram o repertório de aprendizagem dos discentes tanto em Matemática como em Língua Portuguesa.

Em relação às mudanças ocorridas no Projeto Pedagógico da escola, não houve harmonia nas falas o que dificultou um entendimento mais plausível das possíveis mudan- 
ças no ambiente escolar. As técnicas educacionais disseram que as ações desenvolvidas nas escolas eram realizadas em parceria com o PME e, para isso, o PPP precisou ser ampliado para melhor atender o problema, pois as crianças puderam ser mais participativas no ambiente escolar, o que preocupava pela falta de estrutura para melhor atendê-los. Os professores 5 e 6 não observaram mudanças a partir da inserção do programa, principalmente porque as atividades eram realizadas de forma separada. Além disso, o professor 11 destacou que não tinha conhecimento do projeto pedagógico da escola.

No que tange à aprendizagem dos alunos, percebe-se contradições das respostas, como se o Programa Mais Educação ocorresse em outras escolas e não na mesma unidade onde dividiam o trabalho docente. De um lado, não teve mudança ou pouca mudança tendo em vista o interesse por parte dos alunos do programa apenas no almoço, e acrescentam que isso ocorreu porque alguns profissionais, que ali estavam, não tinham compromisso com o trabalho, o que, para o professor 5 , a participação dos alunos no programa implicou aumento da indisciplina na sala regular de ensino. Mas de outro lado, mesmo que os alunos participassem das atividades por conta do almoço, observaram que na aprendizagem houve mudanças, melhorou a convivência, desenvolveram a cooperação, socialização, oralidade, ampliaram as práticas de higiene, esporte e danças. Apesar disso, para o professor 10, percebeu-se que o PME contribuiu quando começou a funcionar como reforço escolar. Segundo a fala de alguns entrevistados, houve mudanças com a implantação do Programa Mais Educação, talvez não como o esperado pela grande maioria dos sujeitos entrevistados. Dessa forma, ressalta-se que a ampliação do tempo escolar surge com a intenção de promover mudanças de comportamento dos alunos e com isso, sua aprendizagem. A construção do currículo escolar é criada com o objetivo de acompanhar as mudanças provenientes da sociedade e garantir práticas que solidifique o processo de ensino e aprendizagem no cotidiano escolar (VALENTINI, 2015).

Para o desenvolvimento do trabalho nas escolas, a participação do Conselho Escolar é de fundamental importância. Esse órgão colegiado, com representatividade em todos os segmentos da escola, tem como objetivo o fortalecimento da participação da comunidade e, segundo as diretoras da Escolas A e B, "foram participativos" na tomada de decisões quando o Programa Mais Educação estava em processo, contribuindo com o fortalecimento de uma gestão democrática e participativa.

Nessa visão, observa-se que os que compuseram o conselho escolar nas unidades de ensino compreendiam a importância da participação deles para a tomada de decisões no ambiente escolar, participando ativamente junto à gestão da escola. O conselho escolar precisa trabalhar lado a lado com a gestão da escola, aconselhando, fiscalizando e, quando necessário, deliberando.

De acordo com Massataru e Merege (2014), o Conselho Escolar é um espaço relevante para o processo de democratização da escola, a partir do momento em que reúne os representantes de toda a comunidade escolar para, na coletividade, discutir, acompanhar e 
definir as disposições referente ao financiamento da escola. É por isso que é importante um resgate da função dos conselhos escolares como instâncias colegiadas, decisivas para o desenvolvimento do trabalho realizado no ambiente escolar, seja ele de ordem pedagógica, administrativa ou financeira.

Diante do exposto e das dificultados observadas para a realização dos trabalhos junto ao Programa Mais Educação, foi necessário perguntar qual a avaliação dos entrevistados com relação a implantação do PME na escola.

Quadro 04 - Avaliação dos entrevistados com relação a implantação do PME na Escola. Itaituba-PA

\begin{tabular}{|c|c|}
\hline Pontos positivos & $\begin{array}{l}\text { "Vejo que o PME tinha tudo para dar certo e melhorar o rendimento dos } \\
\text { alunos na aprendizagem e na formação como um todo" (DA). } \\
\text { "Estimular a criatividade, habilidades artísticas dos alunos em um curto } \\
\text { espaço de tempo" (P1A). } \\
\text { "Trabalhar bem o lado lúdico com o educando devido os diversos recursos } \\
\text { pedagógicos que foram adquiridos através das oficinas que foram ofertados } \\
\text { e aderidos pela escola" (P5A). } \\
\text { "[...] O programa veio mobilizar para melhoria do desempenho educacional e } \\
\text { um dos pontos positivos, foi o combate à fome, mesmo porque sabemos que } \\
\text { nosso alunado é de baixa renda, e a comida oferecida ameniza um pouco a } \\
\text { situação de alguns alunos" (P7B). } \\
\text { "As oficinas são boas e ótimas para se trabalhar o português e a matemática } \\
\text { de forma Lúdica" (P9B). } \\
\text { "As oficinas de dança, pintura, desenho, capoeira etc." (P10B). }\end{array}$ \\
\hline Pontos negativos & $\begin{array}{l}\text { "A falta de espaços, falta de organização do município para iniciar e terminar } \\
\text { dentro do prazo e tempo definidos, falta de formação aos gestores escola- } \\
\text { res e aos conselhos foram um dos empecilhos para o alcance de melhores } \\
\text { resultados" (DA). } \\
\text { "Alguns monitores despreparados, pais infrequentes, falta de estrutura física } \\
\text { adequada" (TEA). } \\
\text { "Faltam estruturas de prédio nas escolas para um melhor desenvolvimento } \\
\text { das atividades e o recuso ainda são poucos" (P3A). } \\
\text { "Educandos ficaram muito indisciplinados, educandos cansados nas aulas } \\
\text { do ensino regular, sem ânimo para estudar [...]; nessas oficinas foram de- } \\
\text { senvolvidos o lado lúdico sem ter de fato a aprendizagem; os pais matricula- } \\
\text { vam os seus filhos apenas com o intuito de deixá-los na escola (P5A). } \\
\text { "Falta de formação continuada para os articuladores do programa. Pouco di- } \\
\text { álogo entre os articulares do programa e os professores das salas comuns" } \\
\text { (TEB). } \\
\text { "A estrutura física da escola. A falta de parceria para a execução de algumas } \\
\text { atividades; pouca participação e valorização da família" (P7B). }\end{array}$ \\
\hline
\end{tabular}

Fonte: elaborada pelo próprio autor a partir dos dados da pesquisa, 2020.

No que tange aos pontos positivos, os entrevistados fazem menção a vários aspectos em relação a avaliação do Programa Mais Educação (aprendizagem, habilidades artísticas, formação como um todo, aquisição de materiais, melhoria no desempenho escolar, trabalho lúdico, dança, capoeira, desenho...). Em primeiro lugar, observa-se no conjunto das respostas o quanto as atividades e habilidades propostas pelo PME contribuíram 
para o crescimento educacional dos discentes, proporcionando, dessa forma, uma melhor aprendizagem diferente da realizada em sala de aula.

Em segundo lugar, chama-se a atenção para as observações relacionadas à cultura como ponto de grande relevância para o PME, haja vista que ela é um canal de aprendizagem produzido a partir das relações sociais existentes na escola. A cultura é resultado de um conjunto de sistemas de significados que definem as ações do homem possibilitando, dessa forma, o entendimento de que qualquer ação social e cultural, práticas sociais que expressam, que comunicam e produzem significados são práticas de significação, discursivas (GODOY; SANTOS, 2014). A cultura se faz importante no contexto escolar como meio de construção coletiva e um meio de compreensão do processo de escolarização e da sociedade em que o indivíduo faz parte.

Em terceiro lugar, frisa-se a importância do esporte, expressa no artigo $4^{\circ}$ do ECA, em que a família, comunidade, sociedade e o poder público têm o dever de assegurar, com absoluta prioridade, a concretização dos direitos referentes à vida, à saúde, à alimentação, à educação, ao esporte, ao lazer, à profissionalização, à cultura, à dignidade, ao respeito, à liberdade e ao convívio familiar e comunitário (BRASIL, 2017, grifo meu).

Em quarto lugar, faz-se destaque para as atividades pedagógicas que contribuíram para o fortalecimento da aprendizagem dos alunos. A organização do trabalho pedagógico proposto pelo PME precisava estar articulada ao conjunto das atividades do currículo escolar e não como atividade sem nexo, sem integração, para que houvesse mudanças positivas e, com isso, melhorar a qualidade de ensino.

Em relação aos pontos negativos, destaca-se a falta de preparo de alguns monitores para a realização do trabalho do PME. Entretanto, é importante deixar claro que a escola em sua prática cotidiana poderia realizar formações com todos os seus colaboradores, como descrito no PCCR, Lei 2.485/2012, em seu artigo $1^{\circ}$, inciso III, o qual estabelece que seja realizada a valorização do servidor através da participação em programas de formação, capacitação e aperfeiçoamento profissional. E de acordo com o artigo 16, inciso IV - cabe ao diretor escolar, implementar atividades de capacitação de recursos pedagógicos (PCCR, 2012 , p. 8). Esse entendimento é reforçado no artigo 76, o qual esclarece que fica assegurado aos trabalhadores da educação o direito à qualificação e aprimoramento profissional [...] para que estes possam desempenhar suas atividades com qualidade, contribuindo para o fortalecimento de uma prática pedagógica que corresponda aos anseios da comunidade escolar e do direito a uma aprendizagem efetiva.

Em relação a ausência dos pais junto às atividades desenvolvidas pelo Programa Mais Educação, foi preocupante. Os pais têm um papel fundamental para a garantia do direito da formação integral dos filhos. A participação deles no ambiente escolar contribui para o desenvolvimento da aprendizagem dos seus filhos, pois "a educação é dever da família e do Estado, inspiradas nos princípios de liberdade e nos ideais de solidariedade 
humana, tendo por finalidade o pleno desenvolvimento do educando, seu preparo para o exercício da cidadania e sua qualificação para o trabalho" (BRASIL, 2017, p. 9).

Por último, fazem críticas à falta de uma estrutura adequada para a realização das atividades do Programa Mais Educação, dizendo que realizar as atividades em espaços adequados contribui para o desenvolvimento das atividades propostas pelo programa, o que não acontece em sua maioria nas escolas pesquisas. $\mathrm{E}$, em decorrência da ausência de uma estrutura adequada, não foi possível corresponder às expectativas da Educação de Tempo Integral.

Dessa forma, observa-se, na avaliação dos entrevistados, que mesmo elencando aspectos positivos, o Programa Mais Educação não atingiu em sua totalidade os objetivos propostos, tendo em vista a dificuldade para a implantação das atividades no ambiente escolar, por falta de elementos que, em sua conjuntura, contribuiriam para a positividade do desenvolvimento das oficinas. Essas problemáticas comprometeram o desenrolar da política pública nas unidades de ensino. A partir desse viés, os sujeitos abaixo deixaram sugestões para melhorar a permanência do Programa Mais Educação nas unidades de ensino:

[...] O Programa Mais Educação deve ser melhorado enquanto estrutura de programa, enquanto formação, enquanto diretriz para continuar. Ao meu ver, foi uma excelente iniciativa do governo, mesmo com todos os desafios. Mas precisa ser uma política que alcance à aprendizagem da criança, com qualidade. Então seria a questão da estrutura da escola, que vem desde a merendeira, porque tem uma contrapartida da prefeitura (CPA).

Penso que deveria investi na estrutura para poder de fato diversificar as aulas extras-classe. Já que dança e capoeira, por exemplo, ficavam sendo executadas em sala normal (P2A).

Formação dos monitores e mais recursos para execução das atividades (P3A).

Que melhorasse os espaços na escola, dando suporte para que as atividades possam acontecer de forma mais efetiva ao invés de ser no improviso (CPB).

Um espaço adequado para cada oficina, monitores melhores, salários muito pouco e uma alimentação diferente para as crianças, praticamente só frango, todos os dias, o dinheiro muito pouco para material didático e pagar monitor (P9B).

Preparar os monitores com capacitações na área pedagógica (P11B).

É perceptível nas respostas dos entrevistados o descontentamento com a falta de uma estrutura para a concretização das atividades. Todavia, é importante dizer que reconhecem que a iniciativa foi relevante por parte do governo, porém fica claro a angústia quanto à logística acerca da realização dos trabalhos no dia-a-dia, o que dificultou todo o trabalho. Mesmo concordando com a positividade do programa, é nítida a insatisfação por falta do real alcance da aprendizagem do aluno com relação a garantia dos padrões mínimos de qualidade por parte da própria escola. Para eles, era preciso ampliação das atividades, melhores condições salariais aos monitores, formação continuada não só para quem trabalhava no programa, mas para quem trabalhava na escola para conhecer de perto essa 
política pública e, com isso, contribuir para um melhor alcance da aprendizagem do aluno. Esses problemas abordados comprometeram a logística e desempenho do PME no cotidiano escolar, refletindo como ponto negativo em alguns aspectos por parte dos servidores da própria escolar.

\section{CONCLUSÃO}

Após o levantamento dos dados e análise dos resultados da pesquisa, chegou-se as seguintes conclusões: A implantação do Programa Mais Educação como Política Indutora de Educação Integral foi uma realidade vivenciada no contexto educacional de Itaituba, em específico, nas duas escolas arroladas na pesquisa. O Programa Mais Educação teve sua vigência até no ano de 2015, quando passou a ser incorporada uma nova nomenclatura, com uma política diferenciada, denominada de Novo Mais Educação.

Com a inclusão do Programa Mais Educação nas duas instituições de ensino, os docentes receberam o PME com preocupação, tendo em vista a falta de crédito neste tipo de projeto indutor de Educação de tempo Integral, não acreditando que daria certo na escola, principalmente por conta da estrutura que não era adequada, além de implicar mais trabaIho para eles, sendo, portanto, apenas uma ação do governo municipal para corresponder aos anseios do Governo Federal.

Em contrapartida, a gestão escolar e os pais foram otimistas com a presença desse novo projeto, pois acreditavam que, a partir da inserção do programa na escola, haveria contribuição para a formação e construção de conhecimento, além do acréscimo de merenda que ajudaria aqueles em condições desfavoráveis matriculados na escola. Não obstante, é importante frisar que antes da presença do PME as escolas não estavam vivenciando um momento que proporcionasse aos alunos aulas diferenciadas, atrativas, que possibilitassem ao próprio ambiente escolar, ampliar a prática de trabalho para proporcionar melhores condições de aprendizagem aos alunos.

Com a presença do Programa Mais Educação na escola, segundo os resultados, surgiram algumas diretrizes, à exemplo disso, a ampliação do tempo de permanência dos alunos na escola com a finalidade de promover a aprendizagem dos discentes. Com as diretrizes, desenvolveram-se trabalhos voltados para as questões culturais, artísticas, conhecimento em matemática e linguística, bem como, incentivo à interação social com os demais colegas que compartilhavam o ambiente de aprendizagem. Essas diretrizes surgiram para contribuir para a redução do abandono, reprovação e distorção da idade/ano.

O Plano de Metas Compromisso Todos pela Educação, alicerce do PDE, criado por meio do Decreto $n^{\circ} 6.094$, de 24 de abril de 2007, tem como objetivo conjugar esforços entre União, Estados, Distrito Federal, Municípios, famílias e comunidade, para que seja assegurada a qualidade da educação básica. Nesse Plano, no Art. $2^{\circ}$, encontram-se as diretrizes voltadas para a ampliação do tempo escolar, como possibilidade de combate 
pela adoção de práticas como aulas de reforço no contraturno, estudos de recuperação e progressão parcial (Art. $2^{\circ}$, inciso IV) (BRASIL, 2009).

Nesse viés, o Compromisso Todos pela Educação reforça a relevância de que sejam aumentadas as possibilidades de permanência do aluno sob a responsabilidade da escola (Art.2 ${ }^{\circ}, \mathrm{VII}$ ), buscando, com isso, uma qualificação dos processos de ensino, característicos da escolarização quanto à participação do aluno em projetos socioculturais e ações educativas (Art. $\left.2^{\circ}, X X V I I\right)$, que tentam dar conta das múltiplas possibilidades e dimensões sociais do território e da cidade (BRASIL, 2009).

A partir do exposto, observa-se a existência de outro marco legal voltado para a implantação de ações direcionadas à educação em tempo integral e que compõe as metas do PDE, materializado como Programa Mais Educação, instituído pela Portaria Normativa Intersetorial $n^{\circ} 17 / 07$, que tem por objetivo promover a Educação Integral de crianças, adolescentes e jovens por meio de atividades socioeducativas, no contraturno escolar, articuladas ao projeto de ensino desenvolvido pela escola (...) (BRASIL, 2009, p. 24).

Assim, as escolas receberam o programa com entusiasmo, sendo abraçado por sua maioria, é importante destacar que o grande problema ocorreu a partir da sua implantação, o que se contrapõe a ideia de o terem recebido bem e abraçado a permanência do programa na escola. O desafio não foi receber o PME, mas executar, realizar os trabalhos na prática, principalmente porque a escola não dispunha de espaço adequado, e as aulas na sala regular de ensino ocorriam em dois horários, no período da manhã, das 7:30m às 11:30m, e no período da tarde, das 14:00h às 18:00h, não dando o tempo e espaço necessários para a realização das atividades. Por isso, Parente (2021, p.13) afirma que

\footnotetext{
é fundamental pensar em como vamos organizar espaços, instituições, recursos e processos, mobilizando educadores e instituições para a formulação de estratégias e alternativas que deem conta de uma formação humana integral, consolidando políticas públicas para a formação de crianças, adolescentes e jovens em processo de escolarização obrigatória.
}

Os trabalhos propostos pelo programa foram executados no contraturno porque a escola mal conseguia trabalhar as três horas, comprometendo as metas do programa, principalmente pelas questões estruturais, que não eram adequadas. Essa inadequação comprometeu a execução do programa, na prática. A chegada do PME ocorria "por meio de articulação institucional e cooperação com as secretarias estaduais e municipais de educação" (CPB). Na verdade, essa articulação ocorria entre Governo Federal e as escolas, tendo em vista que o recurso era repassado diretamente paras as unidades executoras que administravam e faziam o pagamento dos monitores. A SEMED fazia apenas o pagamento dos coordenadores que eram funcionários efetivos.

Para Cavaliere (2015), o PME é uma experiência indutora que leva às escolas recursos financeiros com o intuito de estimular e diversificar a prática pedagógica e os objetivos. 
Porém, é perceptível as enormes dificuldades vivenciadas para sua concretização. As escolas, principalmente nas grandes cidades, não têm muito a oferecer em termos de espaço, tempo e profissionais. Mesmo havendo investimento, os recursos não eram suficientes para um atendimento eficaz, predominando ainda o mínimo nas escolas brasileiras, impedindo de se fazer uma boa educação, restringindo os trabalhos à aplicação dos conteúdos, o que não poderia ser diferente.

Para Barros e Francos (2014), a formação do professor contribui para a formação do aluno, pois eles estão em processo de interação contínua, o que facilita o processo de ensino e aprendizagem. Ensinar é uma atribuição do professor que acompanha o seu ofício desde os tempos mais remotos, de modo que o aluno se aproprie de forma individualizada deste conhecimento. Assim, é preciso que esta formação profissional capacite o professor para ser agente de transformação pedagógica e, consequentemente, social.

De modo geral, os entrevistados disseram que algumas formações existiram durante o processo de implantação do PME, mas não foram suficientes para uma compreensão da totalidade do programa, de suas diretrizes, de sua contribuição para a aprendizagem do aluno, resultado da falta de uma maior articulação por parte da SEMED com a direção das escolas, para que fosse dado suporte técnico necessário, com vista a melhoria dos resultados.

As formações ou treinamento não estavam presentes no Projeto Político Pedagógico (PPP). Destaca-se ainda que, para as coordenadoras destas instituições de ensino, independente da autorização da secretaria, as escolas sempre buscaram nos limites de uma gestão democrática e participativa fazer formação com os professores e monitores com o objetivo de proporcionar a todos a compreensão de como a política pública estava sendo implantada na escola. Com a criação do programa Mais Educação, os profissionais passaram a ser vistos como os principais protagonistas das atividades, recaindo, na maioria das vezes, sobre eles o sucesso ou fracasso escolar nos resultados finais. Porém, apesar dos investimentos oriundos do Governo Federal, a precarização dos trabalhos é, em certa medida, resultado das dificuldades de uma gestão deficiente, na qual, na maioria das vezes, o governo deixa que a escola, em seus limites, realize o trabalho mesmo sem as condições necessárias.

Neste sentido, pensar em uma educação de tempo integral é pensar também em uma formação para o professor que vai trabalhar com alunos com jornada escolar diferenciada daquela já vista na esfera pública da atualidade. Requer maior entendimento da funcionalidade dessa nova concepção de trabalho para modificações da prática docente e da própria rotina da escola. Todavia, não ficou claro como eram essas formações, se atendiam os anseios da escola de tempo integral, pois "o processo de formação docente é imprescindível para que a escola de tempo integral consiga alcançar melhores resultados" [...] (VIDAL, 2017, p. 16522). Dessa forma, era preciso conhecer que escola era essa, que tipo de aluno formar e como trabalhar seguindo essa nova estratégia de trabalho, compreendendo essa nova concepção de educação para que as metas e objetivos fossem alcançados. 


\section{REFERÊNCIAS}

AGUIAR, Maria Sousa. Educação em Tempo Integral: Estudo da Trajetória do Programa Mais Educação (PME) nas escolas Estaduais de Santarém - PA no período de 2009 a 2015. Disponível em: http://www.ufopa.edu.br/ppge/images/dissertacoes/turma_2015/maria_sousa_aguir.pdf. Acesso em: 10 jul. 2018.

BARROS, Marta Silene; FRANCO, Sandra Aparecida Pires. Formação de professores: uma análise da Dialética Materialista como base da Prática Educacional. III Jornada de Didática, Desafios para a docência e II Seminário de Pesquisa do CEMAD, 2014. Disponível em:http://www.uel.br/ eventos/jornadadidatica/pages/arquivos/III\%20Jornada\%20de\%20Didatica\%20\%20Desafios\%20 para\%20a\%20Docencia\%20e\%20II\%20Seminario\%20de\%20Pesquisa\%20do\%20CEMAD/FORMACAO\%20DE\%20PROFESSORES\%20UMA\%20ANALISE\%20DA\%20DIALETICA.pdf. Acesso em: 29 dez. 2019.

BRASIL. Lei de Diretrizes e Bases da Educação Nacional. Lei no 9.394 de 20 de dezembro de 1996. Disponível em: https://www2.senado.leg.br/bdsf/bitstream/handle/id/70320/65.pdf. Acesso em: 30 dez. 2019.

BRASIL. Lei № 8.186, de 23 de junho de 2015. Disponível em: file://D:/Users/CLIENTE/Downloads/ LEI_PEE_PAR\%C3\%81.pdf. Acesso em: 18 nov. 2020.

BRASIL. Estatuto da Criança e do Adolescente - ECA. Lei Federal N ${ }^{\circ} 8.069$, de 13 de junho de 1990. Versão Atualizada, 2017. Disponível em: https://www.chegadetrabalhoinfantil.org.br/wpcontent/uploads/2017/06/LivroECA_2017_v05_INTERNET.pdf. Acesso em: 04 jan. 2020.

BRASIL. LDB - Lei de diretrizes e bases da educação nacional. Brasília: Senado Federal, Coordenação de Edições Técnicas, 2017. Disponível em: https://www2.senado.leg.br/bdsf/bitstream/ handle/id/529732/lei_de_diretrizes_e_bases_1ed.pdf. Acesso em: 04 jan. 2020.

BRASIL. Plano Nacional de Educação PNE 2014 - 2024. Linha de Base. Diretoria de Estudos Educacionais DIRED. Brasília, 2015. Disponível em: file://D:/Users/Bar\%C3\%A30\%20R.\%20Branco/Downloads/pne_2014_2024_linha_base.pdf. Acesso em: 26 dez. 2019.

BRASIL. Relatório de Avaliação Econômica e Estudos Qualitativos. O Programa Mais Educação. Ministério da Educação. São Paulo, 2015. Disponível em: https://www.redeitausocialdeavaliacao. org.br/wpcontent/uploads/2015/11/relat_Mais_Educa\%C3\%A7\%C3\%A3o_COMPLETO_20151118. pdf. Acesso em: 22 dez. 2019.

BRASIL. Ministério da Educação. Secretaria de Educação Básica. Diretoria de Currículos e Educação Integral. Manual Operacional de Educação Integral. Brasília - DF, 2012. Disponível em: http://portal.mec.gov.br/index.php?option=com docman\&view=download\&alias=11452-manual-operacional-de-educacao-integral-2012-pdf\&ltemid=30192. Acesso em: 04 fev. 2019.

BRASIL. Conselho Nacional de Educação. Organização Escolar, 2017. Disponível em: http://www. cnedu.pt/content/noticias/CNE/Organizacao_Escolar_o_tempo-2.pdf. Acesso em: 04 fev. 2019.

BRASIL. Ministério da Educação. Fundo Nacional da Educação, 2017. Disponível em: https:// www.fnde.gov.br/programas/pdde/sobre-o-plano-ou-programa/sobre-o-pdde. Acesso em: 08 abr. 2020. 
BRASIL. Ministério de Educação. Secretaria de Educação Básica. Diretoria de Currículos e Educação Integral. Manual Operacional de Educação Integral, 2012. Disponível em: http://portal.mec. gov.br/index.php?option=com_docman\&view=download\&alias=11452-manual-operacional-de-educacao-integral-2012-pdf\&ltemid=30192. Acesso em: 22 jul. 20.

BRASIL, Rozineide Souza. O Programa Mais Educação e a Gestão Democrática: A experiência de uma escola municipal em Belém/PA, 2015. 185 f. Dissertação (Mestrado em Educação) - Universidade Federal do Estado do Rio de Janeiro, Rio de Janeiro, 2015.

BRASIL, Rozineide Souza. Educação Integral de mais tempo mais espaços e atividades educacionais de diferentes naturezas. Portal do professor, 2015. Disponível em: http://portaldoprofessor.mec.gov.br/conteudoJornal.html?idConteudo=3854. Acesso em: 05 jan. 2010.

CARDOSO, Solange. Ciclo de carreira docente: O que dizem as pesquisas Brasileiras? Disponível em: https://educere.bruc.com.br/arquivo/pdf2017/24528_13853.pdf.. Acesso em: 27 jul. 2020.

CAVALIERE, Ana Maria Villela. Educação Integral de mais tempo mais espaços e atividades educacionais de diferentes naturezas. Portal do professor, 2015. Disponível em: http://portaldoprofessor.mec.gov.br/conteudoJornal.html?idConteudo=3854. Acesso em: 05 jan. 2020.

COLARES, Maria Lília Imbiriba Sousa et al. Educação Infantil: o papel do gestor escolar para a promoção da educação integral da criança. Cadernos de Pesquisa, São Luís, v. 23, n. 3, set./dez. 2016. DOI: http://dx.doi.org/10.18764/2178-2229.v23n3, p44-54.

GODOY, Elenilton Vieira; SANTOS, Vinício de Macedo. Um olhar sobre a Cultura. Educação em Revista. Belo Horizonte. V. 30, 2014. Disponível em: http://www.scielo.br/pdf/edur/v30n3/v30n3a02. pdf. Acesso em: 04 jan. 2020.

ITAITUBA. Prefeitura Municipal de Itaituba. Resgatando um pedaço da História de Itaituba, 2020. Disponível em: <http://www.itaituba.pa.gov.br/paginas/apresentacao. Acesso em: 30/03/2020.

MASSATARU, João Carlos; MEREGE, Sonia Regina Leite. Os desafios da Escola Pública Paranaense na Perceptiva do professor PDE. Versão Online, 2014. Disponível em: http://www. diaadiaeducacao.pr.gov.br/portals/cadernospde/pdebusca/producoes_pde/2014/2014_uenp_gestao_artigo_joao_carlos_massataru.pdf. Acesso em: 04 dez. 2019.

PARANÁ. Orientações para implementação da Educação em Tempo Integral em Turno Único, 2012. Disponível em: http://www.gestaoescolar.diaadia.pr.gov.br/arquivos/File/sem_pedagogica/ fev_2013/documento_referencia_eti_turno_unico.pdf. Acesso em: $17 \mathrm{dez} .19$.

PARENTE, Cláudia da Mota Darós. Políticas Públicas: possibilidades e potencialidades da educação integral. Revista Exitus, Santarém/PA, Vol. 11, p. 01-14, e020180, 2021.

PESTANA, Simone Freire Paes. Letramento e o Programa Mais Educação: Concepção e Prática (s) para uma Educação Integral?. 2013.

SANTOS, Marilene de Fátima Pacheco. O Programa Mais Educação e o Aproveitamento Escolar nos anos iniciais do Ensino Fundamental na Rede Pública Municipal: Percepções de 
Mães e Alunos. Dissertação de Mestrado em Diversidade Cultural e Inclusão Social, Feevale, Novo Hamburgo-RS, 2016.

VALENTINI, Camila Altmayer. Currículo Escolar e Mais Educação: Um diálogo possível? 2015. Disponível em: https://catalogodeteses.capes.gov.br/catalogo-teses/\#!/. Acesso em: 20 maio 2019.

VIANNA, Cláudia Pereira. O sexo e o gênero da docência, 2001. Disponível em: https://www.scielo.br/pdf/cpa/n17-18/n17a03.pdf. Acesso em: 27 jul. 2020.

VIDAL, Soraya Cunha. Formação de Professores e Educação Integral: palavras docentes acerca de suas concepções. IV Seminário Internacional de Representações, Subjetividade e Educação - SIRSSE, 2017. Disponível em: https://educere.bruc.com.br/arquivo/pdf2017/23896_12229. pdf. Acesso em: 07 jan. 2020.

WERLE. Flávia Obino Corrêa. Práticas de Gestão e Feminização do Magistério, 2005. Disponível em: https://www.scielo.br/pdf/cp/v35n126/a05n126.pdf. Acesso em: 27 jul. 2020. 